\title{
Digital Mapping of Techno-Economic Performance of a Water-Based Solar Photovoltaic/Thermal (PVT) System for Buildings over Large Geographical Cities
}

\author{
Santhan Reddy Penaka ${ }^{1,2}\left(\mathbb{D}\right.$, Puneet Kumar Saini ${ }^{1,3}$, Xingxing Zhang ${ }^{1, *} \mathbb{D}$ and \\ Alejandro del Amo ${ }^{4}$ \\ 1 Energy Technology, Dalarna University, 79188 Falun, Sweden; santhanreddypenaka@gmail.com (S.R.P.); \\ pks@du.se (P.K.S.) \\ 2 Penaka Solar, 78452 Borlänge, Sweden \\ 3 Department of Engineering Science, Uppsala University, 75236 Uppsala, Sweden \\ 4 Abora Solar Company, 50196 Zaragoza, Spain; adelamo@abora-solar.com \\ * Correspondence: xza@du.se; Tel.: +46-(0)23-77-87-89
}

Received: 25 June 2020; Accepted: 21 August 2020; Published: 27 August 2020

\begin{abstract}
Solar photovoltaic thermal (PVT) is an emerging technology capable of producing electrical and thermal energy using a single collector. However, to achieve larger market penetration of this technology, it is imperative to have an understanding of the energetic performance for different climatic conditions and the economic performance under various financial scenarios. This paper thus presents a techno-economic evaluation of a typical water-based PVT system for a single-family house to generate electricity and domestic hot water applications in 85 locations worldwide. The simulations are performed using a validated tool with one-hour time step for output. The thermal performance of the collector is evaluated using energy utilization ratio and exergy efficiency as key performance indicators, which are further visualized by the digital mapping approach. The economic performance is assessed using net present value and payback period under two financial scenarios: (1) total system cost as a capital investment in the first year; (2) only $25 \%$ of total system cost is a capital investment and the remaining $75 \%$ investment is considered for a financing period with a certain interest rate. The results show that such a PVT system has better energy and exergy performance for the locations with a low annual ambient temperature and vice versa. Furthermore, it is seen that the system boundaries, such as load profile, hot water storage volume, etc., can have a significant effect on the annual energy production of the system. Economic analysis indicates that the average net present values per unit collector area are 1800 and 2200 EUR, respectively, among the 85 cities for financial model 1 and financial model 2. Nevertheless, from the payback period point of view, financial model 1 is recommended for locations with high interest rate. The study is helpful to set an understanding of general factors influencing the techno-economic performance dynamics of PVT systems for various locations.
\end{abstract}

Keywords: PVT; water-based PVT; techno-economic analysis; digital mapping

\section{Introduction}

\subsection{Background and Existing Studies}

The concept of "electrify everything" considers solar energy as a key renewable technology with an aim of de-carbonization of domestic heating demand [1]. The rapid growth in photovoltaic (PV) installation capacity from the last few years has further strengthened the importance of PV as the main driver of renewable transformation [2]. PV remains an interesting subject area for many researchers, 
global leaders, and manufacturers because of its reliability, sustainability, ease of installation, and economic feasibility [3]. However, the concurrence of heat/electricity demand and limited roof area in domestic dwellings does require technologies which can generate energy efficiently in both thermal and electrical form. Therefore, there is a huge potential for well-designed systems by combining both solar PV and solar thermal technologies. A relatively new commercialized concept of solar photovoltaic/thermal (PVT) technology can achieve such a goal by generating both electrical and thermal energy together using a single panel [4]. Realizing its importance, the Solar Heating and Cooling Program (SHC) of the International Energy Agency (IEA) has initiated Task 60 for PVT applications and solutions to Heating, Ventilation and Air Conditioning (HVAC) systems in buildings [5]. The task has been active from January 2018 and has built a huge knowledge base around PVT systems for its use in domestic and industrial applications.

PVT systems can be categorized in several ways, however, the most common is based on the heat-transfer medium (air-based/liquid-based) used in the PVT collector [6]. The liquid-based types are dominating the current PVT market in terms of the number of installations due to high efficiency, and ease of integration in existing hydronic systems [7]. In a standard liquid-based PVT collector, the heat carrier is usually water or brine mixture, which is allowed to circulate in a heat exchanger behind the PV cells. The circulation results in a heat transfer through the back sheet of the module, which raises the fluid temperature enough to use for various applications such as, e.g., hot water and swimming pool heating. From a technical perspective, PVT technology is well developed, and it can be coupled with various energy systems. For instance, it can go hand-in-hand with the emerging awareness of heat pump technology with/without borehole storage [8]. However, the current main barriers in PVT development and deployment are lack of testing standards, uncertain financial incentives, and business models across different regions in a niche market. Therefore, the business potential of PVT solution has not been fully explored, although it can be a very efficient solution for domestic and industrial heating requirements.

There are several studies concerning the techno-economic analysis of PVT collectors with a focus on the component and system design [4,9-12]. The most common way is to assess the energetic performance firstly and then carry out an economic evaluation based on dependent variables $[4,9,10,12-16]$. The prevalent energy performance indexes are energy efficiency and exergy efficiencies [6] while the most popular economic indicators are represented by levelized cost of energy (LCOE), net present value (NPV), and payback period [4]. To name a few studies for technical evaluation, Fudholi et al. [13] investigated electrical and thermal performances on PVT water-based collectors by testing with specific inputs parameters ranging from 500 to $800 \mathrm{~W} / \mathrm{m}^{2}$ solar irradiance and mass flow rate of 0.011 to $0.041 \mathrm{~kg} / \mathrm{s}$. The test concluded that absorber performed better at a mass flow rate of $0.041 \mathrm{~kg} / \mathrm{s}$ and under $800 \mathrm{~W} / \mathrm{m}^{2}$ irradiance, with a measured PV efficiency of $13.8 \%$, thermal efficiency of $54.6 \%$, and overall collector efficiency of $68.4 \%$ [13]. Shah and Srinivasa [17] developed a theoretical model using COMSOL multi-physics validation tool with standard test conditions (STC) to measure the PV improved efficiency when it is integrated with hybrid PVT system. Another study performed by Buonomano [18] developed a numerical model to conduct the technical and economic analysis of PVT collectors and compared it with conventional PV collectors installed in Italy. The tool was validated using TRNSYS platform for the energetic and economic performance of systems integrated with PV and PVT collectors together. Yazdanpanahi [19] presented a numerical simulation and experimental validation for evaluation of PVT exergy performance using a one-dimensional steady thermal model and a four-parameter current-voltage model for a PVT water collector. In terms of economic studies, $\mathrm{Gu}$ et al. [4] developed an analytical model on basis of combinations of Monte Carlo method to analyze techno-economic performances of solar PVT concentrator for Swedish climates, which considered several essential input uncertainties whereas economic variables were initially assessed. The developed model has expressed results for capital cost range between 4482 and $5378 \mathrm{SEK} / \mathrm{m}^{2}$ for $10.37 \mathrm{~m}^{2}$ system cost during the system lifespan of 25 years. The paper results indicated an LCOE of $1.27 \mathrm{SEK} / \mathrm{kWh}$ and NPV of 18,812 SEK with a simple payback period of 10 years. It was concluded that the most 
important sensitivity factor is average daily solar irradiation followed by debt to equity ratio, capital price, regional heating price, and discount rate. Herrando et al. [20] performed techno-economic analysis of hybrid PVT systems for electricity and domestic hot water (DHW) demand for a typical house in London and concluded that such systems can meet $51 \%$ of electricity demand and $36 \%$ of DHW demand even during low solar global horizontal irradiation (GHI) and ambient temperatures. In the economic aspect, it was also concluded that hybrid PVT technology has better energy yield per unit roof area, which can result in attractive NPV for investor while mitigating the $\mathrm{CO}_{2}$ emissions. Riggs et al. [10] developed a combined LCOE techno-economic model for different types of hybrid PVT systems applied for process heat application in the United States. The sensitivity analysis of parameters affecting the levelized cost of heat $(\mathrm{LCOH})$ was determined using technical, financial, and site-specific variables. Ahn et al. [21] studied the importance of energy demands, solar energy resources, and economic performances of hybrid PVT systems at different PV penetration levels using Monte Carlo method, whereas the study found that irrespective of PV penetration levels, the uncertainties in energy demands and solar irradiance can influence the energy performance of PVT systems. Heck et al. [22] conducted Monte Carlo method for LCOE based on probability distribution, which concluded that this method provides more realistic information on risk/uncertainty, which triggers more scope of potential investment on electricity generation. However, author defended that the method is slightly complex to use point values.

There is more literature available regarding PVT techno-economic performance than what is presented in this study. However, most of the existing studies focused on a single climate, with a straightforward economic-financial analysis. Furthermore, complicated procedures or individual software (e.g., TRNSYS, Polysun) are used to estimate the performance of PVT collectors, which require detailed modelling skills, and higher computation time. There is a lack of a comprehensive simulation of PVT techno-economic performance through a common tool over a large geographic area, aiming for application feasibility and business potentials. Moreover, many studies have reported the solar energy resource potential of buildings at different spatial scales using digital mapping methods, such as digital numerical maps [23], digital surface model [24], satellite imageries and geographic information systems $[25,26]$, and multi-scale uncertainty-aware ranking of different urban locations [27], which provide direct evaluations for solar application, leading to robust planning decisions. Nevertheless, no study has yet been found for mapping of techno-economic performance of PVT systems.

As a result, this paper aims to fill this research gap by utilizing a validated simulation tool to perform a comprehensive techno-economic performance simulation for a wide range of cities. The results are further analyzed and visualized using a digital numerical mapping approach to establish a comparison among various regions.

\subsection{Aim and Objectives}

This study aims at simulation and mapping of the energetic and economic indicators of a typical PVT system over different regions to establish a digital performance database for various key performance indicators (KPIs). The economic feasibility of the PVT collector is obtained and compared under various financial scenario models. The data obtained from simulations are used to establish a simple correlation between variables affecting the PVT system.

The main objectives of this paper are to:

(1) Assess the thermal and electrical performance of a typical PVT system [6] in 85 large geographical cities using a validated simulation tool.

(2) Evaluate the economic performance using NPV and payback period using two financial scenarios.

(3) Analysis and visualization of energy and economic performance.

The significance of this paper lies in (1) understanding of typical PVT components behavior at the system level and (2) mapping of the collector energetic and economic performance for different 
climatic conditions across the world. This research results would reflect the concrete developments in this subject area and help the promotion of potential markets, e.g., discovering the economic feasibility of the PVT system and feasible financial solutions to the PVT system in different regions. This paper evaluates the related business benefits of a typical PVT system, which would help to develop a database as repository of PVT performances in different regions and contexts. The research results will be useful for researchers, planners, and policymakers to further evaluate PVT potentials in a net-zero/positive-energy district towards energy surplus and climate neutrality.

\section{System Description and Research Methodology}

\subsection{Water-Based PVT Collector}

Among the different types of PVT technology, the water-based PVT is the most common one that has great possibilities for system integration [28]. This PVT collector type is structured similarly to the typical flat-plate collector, as shown in Figure 1. It is a sandwiched structure comprising several layers, including a glass cover placed on the top, a layer of PV cells or a commercial PV lamination laid beneath the cover with a small air gap in between, heat-exchanging tubes or flowing channels through the absorber and closely adhered to the PV layer, and a thermally insulated layer located right below the flow channels. All layers are fixed into a framed module using adequate clamps and connections. In the heat-exchanging tubes, water is the most commonly used heat carrier medium due to high specific heat capacity and ease of availability. The glass cover is often optional depending on the system design priority for the type of output required (i.e., electricity or heat). The glass cover helps to reduce heat convection losses, but it also causes high solar reflectance losses and thus lowers optical efficiency. In many cases, the glass cover is used when higher heat output is expected, while it is removed when the system is optimized for higher electrical output.

The electrical efficiency of PV cells increases when the pumped cooled water flows across the rigid series or parallel tubes. The flow control is an important factor to achieve overall high performance of the PVT collectors [29]. In addition to electricity production, hot water is generated by absorbing extra heat from the PV layer, which can be used for several applications. The electrical and thermal efficiencies of PVT generally depend on the PV cell type, fluid temperature, fluid flow rate, flow channel size/configuration, and ambient climatic conditions. The collector energetic performance can be measured in terms of energy utilization ratio and exergy efficiency [19].
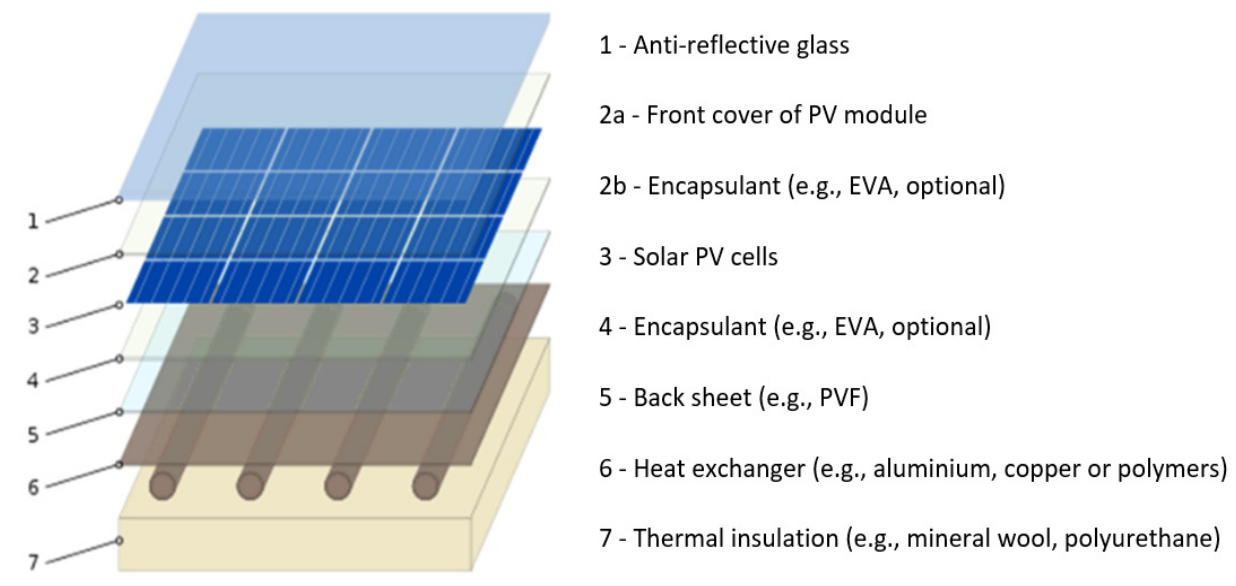

Figure 1. Schematic cross-section of a covered flat-plate photovoltaic thermal (PVT) collector [30].

This paper will focus on a typical PVT collector developed by a Spanish manufacturer named Abora solar. The collector is available on the market, and more than $5700 \mathrm{~m}^{2}$ of the gross collector is installed for a broad range of applications. The collector is a covered PVT type with an additional layer of glass on the top of the collector (in addition to a glass layer for PV cells) to reduce the heat convection 
losses. The rated power of the collector is $365 \mathrm{~W}$ at standard test conditions (STC) with a collector area of $1.96 \mathrm{~m}^{2}$ consisting of 72 monocrystalline cells. The main specifications and characteristics of analyzed PVT collector are shown in Table 1.

Table 1. Specifications and characteristics of the modeled PVT collector.

\begin{tabular}{cc}
\hline Parameter & Description \\
\hline Length $\times$ width $\times$ thickness & $1970 \mathrm{~mm} \times 995 \mathrm{~mm} \times 107 \mathrm{~mm}$ \\
Gross collector area & $1.96 \mathrm{~m}^{2}$ \\
Number of PV cells & 72 \\
Cell type & Monocrystalline \\
Rated power & $365 \mathrm{Wp}$ \\
Electric efficiency at STC & $17 \%$ \\
Thermal efficiency at STC & $70 \%$ \\
Temperature coefficient of PV & $-0.41 \% /{ }^{\circ} \mathrm{C}$ \\
Thermal efficiency at zero mean temperature & 0.7 \\
Coefficient of thermal losses, $\mathrm{a}_{1}$ & $5.98 \mathrm{~W} / \mathrm{m}^{2} \cdot \mathrm{K}$ \\
Coefficient of thermal losses, $\mathrm{a}_{2}$ & $0.021 \mathrm{~W} / \mathrm{m}^{2} \cdot \mathrm{K}^{2}$ \\
Internal water volume & $1.78 \mathrm{~L}$ \\
\hline
\end{tabular}

\subsection{Key Performance Indicators}

The performance of such PVT collectors is evaluated using standard key performance indicators. The performance of a collector over a specified period can be quantified using the energy utilization ratio $\left(\eta_{e}\right)$, which is defined as below [31]:

$$
\eta_{e}=\frac{\text { Output energy } y_{\text {electrical }}}{G H I \times \text { collector area }}+\frac{\text { Output energ } y_{\text {thermal }}}{G H I \times \text { collector area }}
$$

where GHI is global horizontal irradiation $\left(\mathrm{kWh} / \mathrm{m}^{2}\right)$, and the collector area is in $\mathrm{m}^{2}$. However, the exergy value of both electricity and heat is different. Electricity can be regarded as pure exergy whereas heat contains some exergy value. To account for this, "energy" is replaced by "exergy", which has the drawback of being somewhat less intuitive. The overall exergy efficiency takes into account the difference of energy grades between heat and electricity and involves a conversion of low-grade thermal energy into the equivalent high-grade electrical energy using the theory of the Carnot cycle. The overall exergy of the PVT $\left(\varepsilon_{e}\right)$. is defined as following expression:

$$
\varepsilon_{e}=\eta_{c} \eta_{t h}+\eta_{e l} \text {. }
$$

Carnot efficiency $\eta_{C}(\%)$ is defined in the following Equation (3)

$$
\eta_{C}=1-\frac{T_{\text {in }}}{T_{\text {out }}}
$$

where $\eta_{t h}, \eta_{e l}, T_{o u t}$, and $T_{\text {in }}$ are thermal efficiency, electrical efficiency, outlet fluid temperature, and inlet fluid temperature, respectively.

NPV is defined as a measurement of cumulative profit calculated by subtracting the present values of cash outflows (including initial cost) from the present values of cash inflows over the PVT collector's lifetime. In this paper, we use NPV to evaluate a single investment to evaluate the acceptability of the project [4]. A positive NPV indicates that the projected earnings generated by a project or investment, exceed the anticipated costs. In general, an investment with a positive NPV will be a profitable one, and the higher NPV means higher benefits. This concept is the basis for the NPV decision rule, which dictates that the only investments that should be made are those with positive NPV values. NPV is calculated using Equation (4) as below:

$$
N P V=\sum_{t=0}^{n-1} \frac{C F_{t}}{(1+r)^{t}}-C_{0}
$$


where, $C F_{t}, r, n, t$, and $C_{0}$. are the cash flow of particular year (SEK), discount rate, number of years, year of NPV evaluation, and capital cost, respectively.

The payback period is the time for a project to break even or recover its initial investment funds, where the cash flow starts to turn positive and can be given as in Equation (5).

$$
P P=T_{\left(C F_{t}>0\right)}
$$

\subsection{Research Methodology}

The simulation is carried using a validated tool developed by the manufacturer of the studied PVT collector. The Abora hybrid simulation tool [32] was used to map the performance across 85 cities shown in Figure 2. The cities were chosen based on population density and geographical coordinates in different countries to represent a large market potential in these regions. A large number of selected locations for analysis are concentrated within Europe, with limited locations in India, United States, and Australia. The selection of locations is also restricted due to the availability of weather and GHI data in the simulation tool. The simulation tool accepts a wide range of design and financial input parameters, e.g., location and weather resources, electrical and thermal demands, local energy tariffs, specific storage volume, PVT panel and installation parameters, interest rate and financing period, etc. The complete list of various inputs used is shown in Table 2. The performance model used in the tool for evaluation of PVT performance is validated in [24], where a heat pump system integrated with 25 PVT modules was monitored, and measurements were also compared with the dynamic simulation model built in TRNSYS for Zaragoza, Spain. This model has observed thermal and electrical performance of collectors is accurate with measured data (4.2\% deviation), however, a slightly higher deviation in heat pump performance was noted due to limitations in the black-box model of the heat pump in the studied energy system.

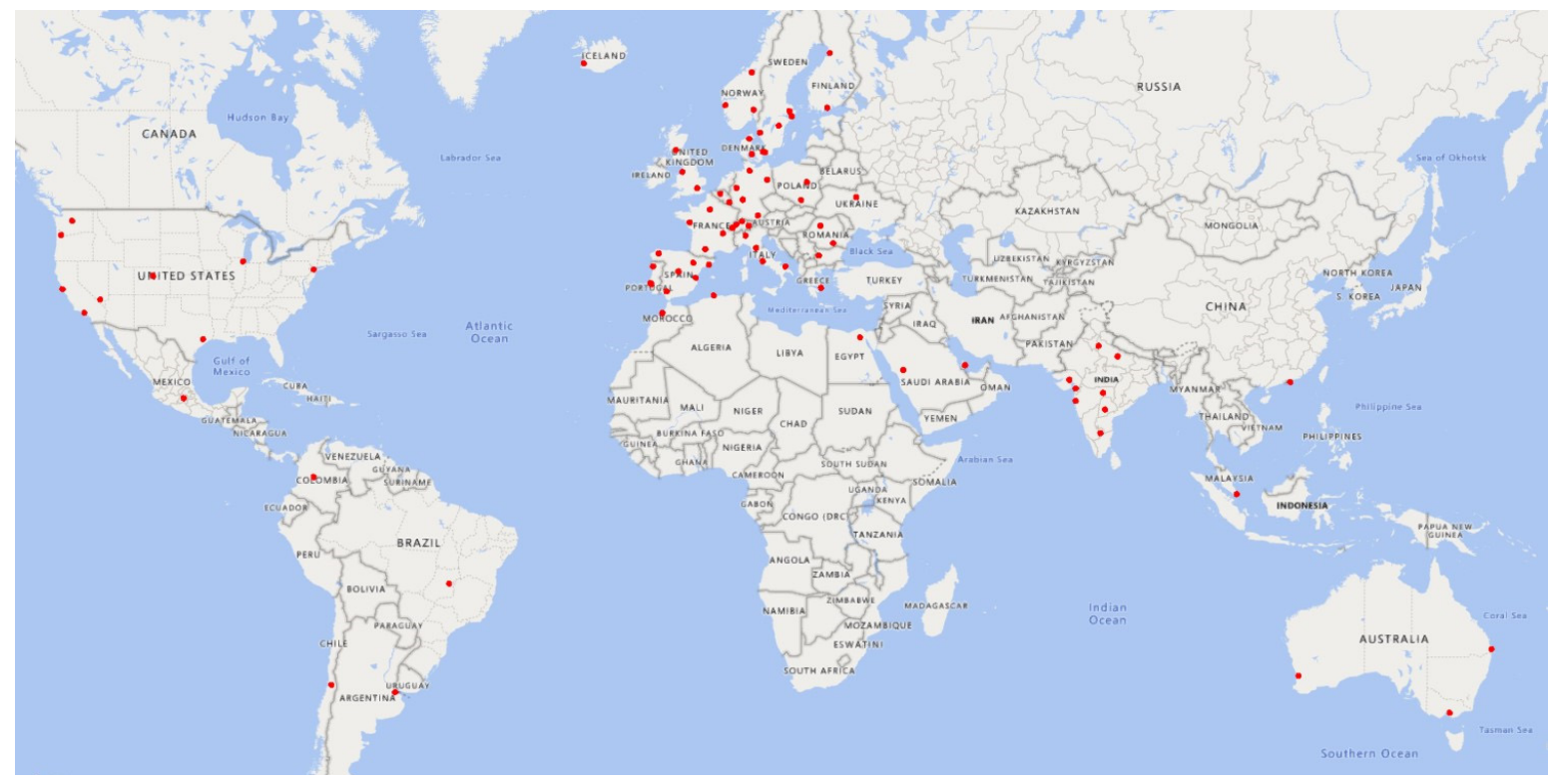

Figure 2. The simulated locations for techno-economic analysis.

This paper further applies the digital numerical map approach based on heat maps to visualize the performance of various indicators across simulated locations. The simulation results for all locations are exported to Microsoft Excel for calculations of energy and exergy efficiency [33]. After this, the results are visualized using QGIS tool, which provides a heat map rendering to design point layer data with a kernel density estimation processing algorithm [34]. Initially, a parametric study of the components at system level is considered according to the operation flow of the simulation tool indicated in the flow chart shown in Figure 3. Then, the simulations are carried with defined boundary conditions and the 
results are represented subsequently as monthly electrical and thermal performances, energy savings, economic parameters such as NPV, and payback period.

Table 2. Technical and economic input parameters.

\begin{tabular}{cc}
\hline Technical Parameters & Economic Input Parameters \\
\hline Type of application (domestic/industrial) & Type of mounting structure \\
Type of demand (hot water/space heating) & Type of inverter \\
Type of auxiliary system & Material profit margin \\
Number of bedrooms & Operation and maintenance margin \\
DHW temperature & Pricing of all system components \\
Dwellings occupancy & Annual maintenance cost \\
Number of collectors & Electricity price increment \\
Collector tilt & Auxiliary fuel price increment \\
Storage tank volume & Financing period models \\
Meteorological parameters (irradiation/ambient temperature/albedo, etc.) & Interest rate \\
Shadow loss percentage & Opening interest rate \\
Number of additional PV panels & \\
\hline
\end{tabular}

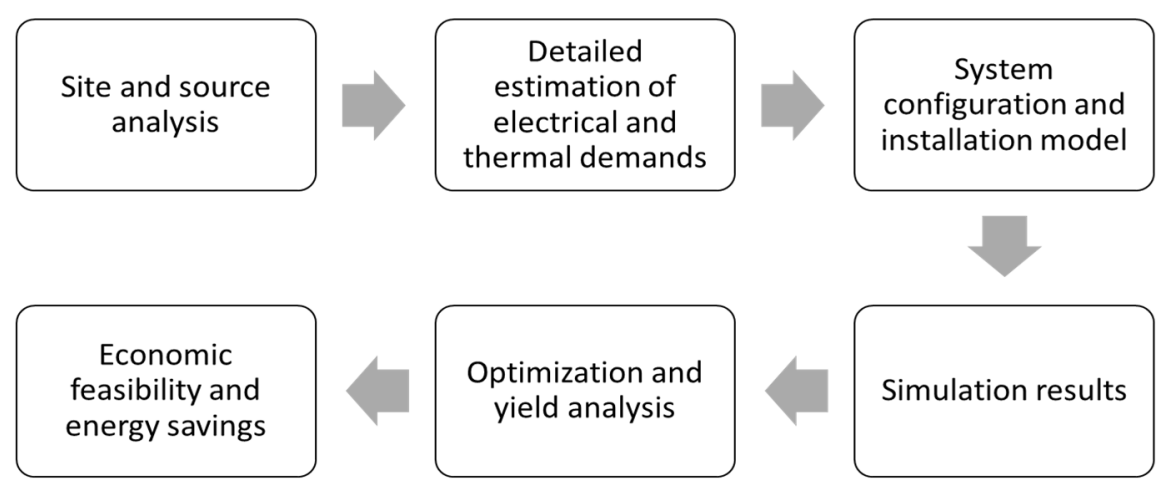

Figure 3. Operation flow of the simulation tool.

This paper also considers the economic performance of the collector in two different financial models, which are described below:

- Model 1: The total system cost is invested in the first year.

- Model 2: Only 25\% of total system cost is a capital investment and the remaining $75 \%$ investment is considered with the financing period with a certain interest rate.

The economic analysis results highlight the economic parameters, such as NPV and payback period per unit collector area, for all locations. Furthermore, the uncertainty and sensitivity parameters are discussed, and the strategy in decision-making for investing in PVT technology is recommended. The digital mapping method is applied to compile and format the techno-economic performance data into a virtual image, which aims to produce a general map with KPIs of such a PVT system that gives appropriate representations of the dedicated areas.

\section{Simulation Tool and Boundary Conditions}

\subsection{Location and Detailed Demand Analysis}

The simulation tool considers the Meteonorm [35] weather database to determine solar and meteorological resources, such as GHI, ambient temp, and wind speed. The thermal and electrical demands change with different categories of buildings, i.e., single and multifamily houses, tertiary buildings (such as hospitals, hotels, and gyms, etc.), and can be selected individually within the tool interface. Specific key parameters are included, such as load profiles, the current auxiliary source of 
electricity, and energy system details. The simulation engine assesses the total monthly and annual total demand depending on inputs for each application. The monthly energy load (L) needed to raise the temperature of supply water to the desired hot water temperature is calculated using Equation (6):

$$
L=m \times C_{p} \times N \times\left(T_{d}-T_{s}\right)
$$

where ' $m$ ' indicates the amount of hot water required per person in a day (in liters), ' $C_{p}$ ' is the specific heat capacity $(\mathrm{J} / \mathrm{kg} \cdot \mathrm{K}),{ }^{\prime} N$ ' is several days in a month (days), ' $T_{d}$ ' is desired water temperature $\left({ }^{\circ} \mathrm{C}\right)$, and ' $T_{s}$ ' cold supply water temperature in $\left({ }^{\circ} \mathrm{C}\right)$. The monthly demand can also be customized based on consumer utilization in that specific month. For a single-family house, the amount of DHW for one person in a day is considered as $28 \mathrm{~L} /$ person/day at $100 \%$ occupancy. The demand is kept constant to minimize the variables in the overall system and, thus, to have a fair comparison of collector performance for various locations. The fraction of occupancy can be parameterized to meet the specific thermal demand for the individual location. For tertiary buildings (such as industrial applications), tools consider a different consumption depending on process characteristics.

This simulation tool offers to choose an auxiliary heating system to meet the load demand. This tool also accommodates for the fact that the total collector electricity generation can be utilized for self-consumption or if there is excess electrical energy, it can be sold to the electricity grid in the context of a positive-energy building.

\subsection{System Variables}

This simulation tool consists of several PVT collectors and also recommends the number of collectors that would be required based on optimization of total demand and the storage tank capacity. The specific volume capacity (v/a), which is ratio of tank volume (liter) to collector gross area $\left(\mathrm{m}^{2}\right)$ can be changed depending on the number of storage duration hours.

The shading loss fraction on PVT modules can be adjusted manually. There is the provision to integrate PV and PVT collectors in a scenario if the thermal demand is first fully met by PVT modules, and electrical demand is not fully covered.

\subsection{Working Principle of the Simulation Tool}

The simulation tool also optimizes the collector and installation parameters based on the demand, availability, and metrological conditions for a particular location. Simulation results highlight essential parameters such as GHI, irradiation on a tilted surface, thermal demand, thermal production, thermal solar coverage, electrical production, total electric and thermal savings, and environmental impact. The maximum power point $\mathrm{P}_{\mathrm{m}}$ (in $\mathrm{kW}$ ) generated by the PV cells is obtained using Equation (7) depending on the global irradiation on the surface of the module $\mathrm{G}\left(\mathrm{W} / \mathrm{m}^{2}\right)$, ambient temperature $T_{a}$ $\left({ }^{\circ} \mathrm{C}\right)$, cell temperature $T_{\mathcal{C}}\left({ }^{\circ} \mathrm{C}\right)$, nominal power of photovoltaic collector $P_{n}(\mathrm{~kW}), G_{\text {STC }}$ irradiance under STC $\left(\mathrm{W} / \mathrm{m}^{2}\right)$, i.e., $1000 \mathrm{~W} / \mathrm{m}^{2}$, and the temperature variation coefficient of power $(\gamma \gamma)\left(\% /{ }^{\circ} \mathrm{C}\right)[36]$.

$$
P_{m}=P_{n} \times \frac{G}{G_{S T C}}\left(1-\gamma\left(T_{c}-25\right)\right)
$$

The cell temperature $T_{\mathcal{C}}$ is linked to the temperature of the absorber plate, which is dependent on the temperature of fluid going in and out of the module. Cell temperature is calculated for each simulation time step based on inlet and outlet temperatures, and electrical output is then calculated depending on the temperature coefficient of the module.

The instantaneous thermal efficiency of the collector is calculated based on Equation (8)

$$
\eta_{t h}=\eta_{o}-a_{1}\left(\frac{T_{m}-T_{a}}{G}\right)-a_{2}\left(\frac{\left(T_{m}-T_{a}\right)^{2}}{G}\right)
$$

where $\eta_{0}$ is optical efficiency, $a_{1}$ is first order heat loss coefficient $\left(\mathrm{W} / \mathrm{m}^{2} \cdot \mathrm{K}\right), a_{2}$ is the second order heat loss coefficient $\left(\mathrm{W} / \mathrm{m}^{2} \cdot \mathrm{K}^{2}\right), T_{m}$ is the average fluid temperature $\left({ }^{\circ} \mathrm{C}\right)$, and $T_{a}$ is ambient temperature 
$\left({ }^{\circ} \mathrm{C}\right)$. The various characteristics of the simulated module are listed in Table 1 and are validated by real measurements as explained in [25].

The temperature leaving the PVT module $T_{o}$ is determined using Equation (9)

$$
T_{o}=T_{i}+\left(\frac{m \cdot C_{p}}{G \cdot \eta_{t h}}\right)
$$

where $T_{i}, m$, and $C_{p}$. represents inlet temperature $\left({ }^{\circ} \mathrm{C}\right)$, fluid mass flow rate $(\mathrm{kg} / \mathrm{s})$, and fluid specific heat $(\mathrm{kJ} / \mathrm{kg} \cdot \mathrm{K})$, respectively. Thermal solar coverage $\left(\mathrm{T}_{\text {solar }}\right)$ is calculated using Equation (10) in this simulation tool

$$
\mathrm{T}_{\text {solar }}(\%)=\frac{\text { Total collector thermal production }(\mathrm{kWh})}{\text { Total thermal demand }(\mathrm{kWh})} \times 100
$$

\subsection{System Pricing and Optimization}

The detailed system cost of the PVT system is defined by customizing each component, such as flat or tilted mounting structure, single-phase or three-phase inverter, material marginal rate, electrical and combustible price escalation rate, annual maintenance cost, etc.

The simulation considers the appropriate dynamic inputs and generates the report of assessment on the key economic performance indicators, i.e., lifetime cash flow with appropriate total annual savings, NPV, and payback period. This simulation tool allows collector economic performance with several financing options shown in Figure 4. For instance:

- The total system cost is invested in the first year as a capital investment.

- The $100 \%$ of total system cost can be invested in several years with monthly payment at a certain open and fixed interest rate.

- The $75 \%$ of total system cost can be invested in several years with monthly payment at a certain open and fixed interest rate and the remaining $25 \%$ of total system cost is to be invested initially as capital investment.

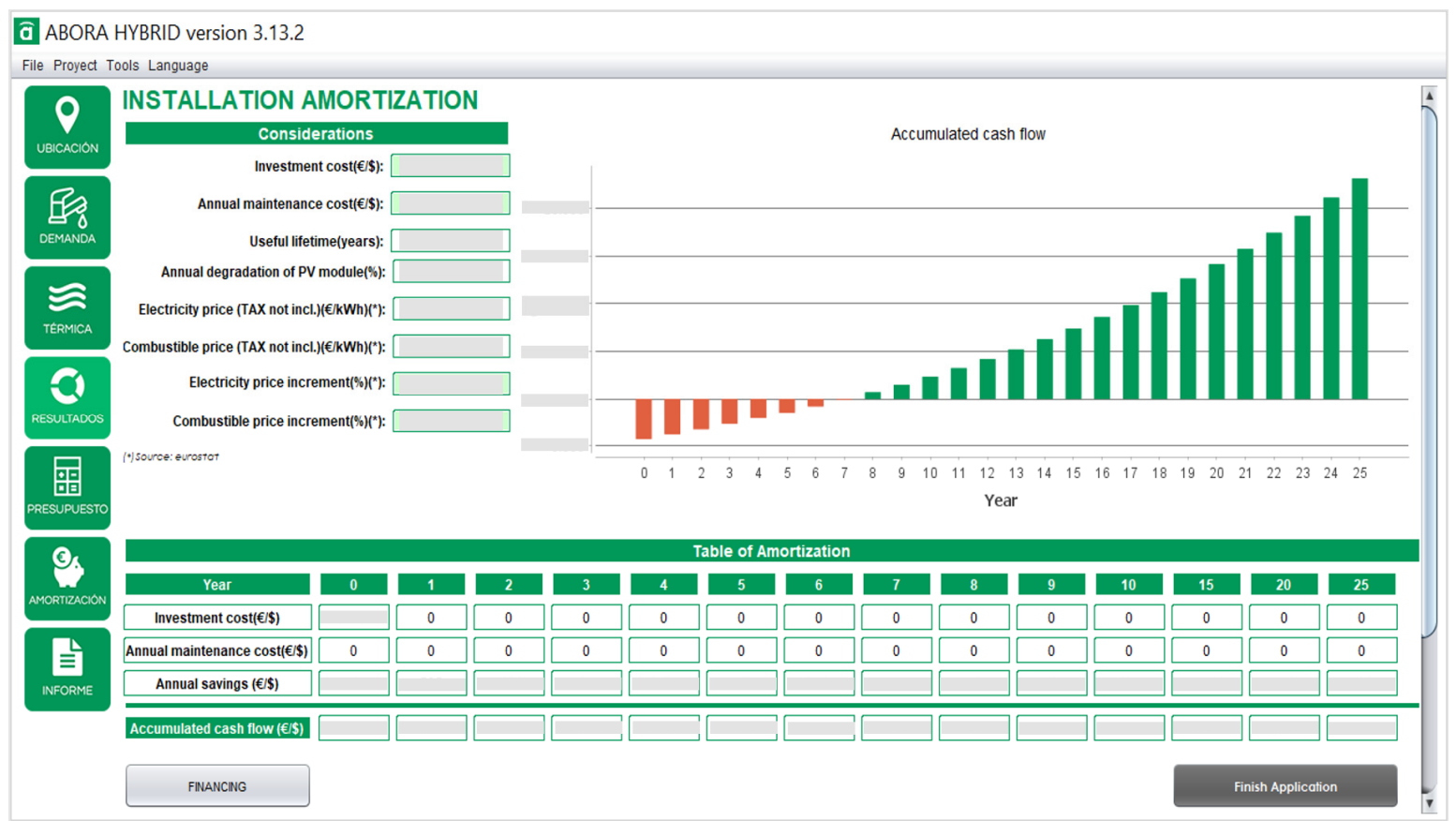

Figure 4. Cost optimization of the PVT system in the simulation tool. 
This simulation tool is also flexible in customizing several real-time scenarios, i.e., the number of payments in a single year and the total number of payments in the entire financing period. The early cancellation interest rate can be applied when the system is to be dismantled during the financing period.

\subsection{Boundary Conditions}

This section pre-determines the boundary conditions for the simulation as shown in Table 3.

Table 3. Boundary conditions for the simulation tool.

\begin{tabular}{|c|c|}
\hline Parameter & Description \\
\hline Type of application & Single-family house \\
\hline Type of demand & Electricity demand and thermal demand for DHW \\
\hline Auxiliary system & Electrical heater \\
\hline Auxiliary system energy price & This is selected individually for each location \\
\hline No. of people in house & 5 \\
\hline DHW temperature & $60^{\circ}$ \\
\hline PVT Collector model & aH72SK \\
\hline No. of collectors & 1 \\
\hline Specific volume capacity & $80 \mathrm{~L} / \mathrm{m}^{2}$ \\
\hline Inclination & $\begin{array}{c}\text { Selected optimally based on a parametric study for maximum } \\
\text { energy production }\end{array}$ \\
\hline Type of mounting structure & Tilted \\
\hline Type of inverter & Single-phase inverter \\
\hline Annual maintenance cost & $\begin{array}{l}\text { Assumed that no maintenance is required for a single collector } \\
\text { to reduce uncertainties }\end{array}$ \\
\hline Electricity and combustible price increment & $6 \%$ per year is assumed for all the location \\
\hline System lifetime & 25 years \\
\hline Interest rate & Selected appropriately for each location \\
\hline
\end{tabular}

Initially, the energy performance of the PVT system is simulated in 85 different locations using the simulation tool. In order to discover and compare the collector energy performance in different locations, the thermal demand is maintained the same in all selected locations. Therefore, the simulated system considers a single PVT collector $\left(1.96 \mathrm{~m}^{2}\right)$, for a single-family house application with 5 people, for the same demand, and the same tank volume for all locations. These assumptions provide a common system boundary to understand the effect of climatic variables and financing parameters on collector performance. Two types of demands are considered as DHW and electricity use in the building. In the electricity model, no price difference in self-consumed and exported power to the grid is considered. In the thermal system configuration, the auxiliary source for the house is the electricity grid with appropriate energy prices for every location. The generated DHW by the collector is utilized for household purposes using a storage tank connected to the auxiliary system which will deliver demand at the desired temperature of $60^{\circ} \mathrm{C}$, as shown in Figure 5. For each location, the installed tilt and azimuth angles are taken optimally based on higher collector production. The specific volume capacity is assumed $80 \mathrm{~L} / \mathrm{m}^{2}$ for all the locations which is equivalent to total $150 \mathrm{~L}$ of storage tank capacity.

In the proposed simplified energy system, PVT collector is directly connected to the tank without any internal or external heat exchanger. The cold water from the tank enters the PVT module, exchanges heat from the absorber, and hot water is fed to the top of the tank. The DHW cold water enters at bottom of the tank, and hot water leaves from top of the tank for DHW supply in the building. The DHW distribution system and associated heat losses are not considered in the analysis. The maximum DHW supply temperature is set at $60^{\circ} \mathrm{C}$, and an electric auxiliary heater is provisioned in the tank for periods when the energy from PVT modules is not enough to meet the DHW load. Electric heater starts and stops at the determined dead band to optimize energy consumption while maintaining the fixed supply DHW temperature. During the periods when tank temperature exceeds the set limit, the energy from 
PVT modules is fed to a heat sink (air/water heat exchanger), and this spilled energy from the collector is not counted as part of useful energy output.

\section{Thermal system configuration}

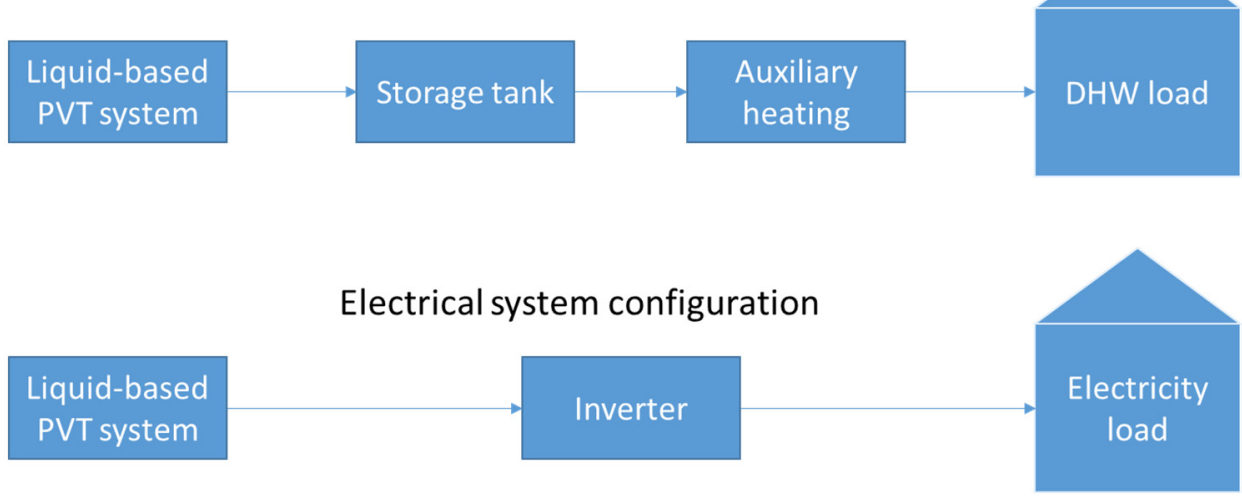

Figure 5. Thermal and electrical system configurations.

In the electrical system configuration, the generated DC power will be converted to AC power using an inverter. Then, it is utilized for household purposes and the remaining will be sent to the electricity grid, whereas the excess electricity demand is taken from the grid connection as shown in Figure 5. As the tilt angle of the PVT collector is a key parameter that will also decide the collector production, a preliminary parametric study is carried for each location to determine the optimal tilt angle for maximum annual collector production.

The total system cost is determined using variables such a module cost, system components cost, annual operation, and maintenance cost. The electricity and auxiliary energy price escalation is assumed to be $6 \%$ per year for all the locations. Various parameters considered for economic analysis are shown in Table 4.

Table 4. Parameters considered for economic analysis.

\begin{tabular}{cc}
\hline Parameter & Value \\
\hline Abora PVT collector & 350 EUR \\
Cost for Connection kit & 128 EUR \\
Tilted mounting structure & 243 EUR \\
Storage tank & 1553 EUR \\
Valve (servo meter) & 127 EUR \\
Flowmeter & 142 EUR \\
Copper tubes & 19 EUR \\
Isolation tubes & 14 EUR \\
Heat sink & 474 EUR \\
Microinverter & 500 EUR \\
Legal regulations & 377 EUR \\
Electricity price increment & $6 \%$ annually \\
System lifetime & 25 years \\
Electricity price & Variable based on each location \\
\hline
\end{tabular}

The payback time and NPV are estimated by considering a reference system using an electric heater. The price of electricity considered for various locations is shown in Figure 6 below.

The economic performance of the collector in two different financial models is evaluated based on:

- Model 1: The total system cost is invested as initial capital investment in the first year;

- Model 2: $25 \%$ of total system cost is capital investment and remaining $75 \%$ is paid within financial period of 7 years with a certain variable interest rate with every location. 


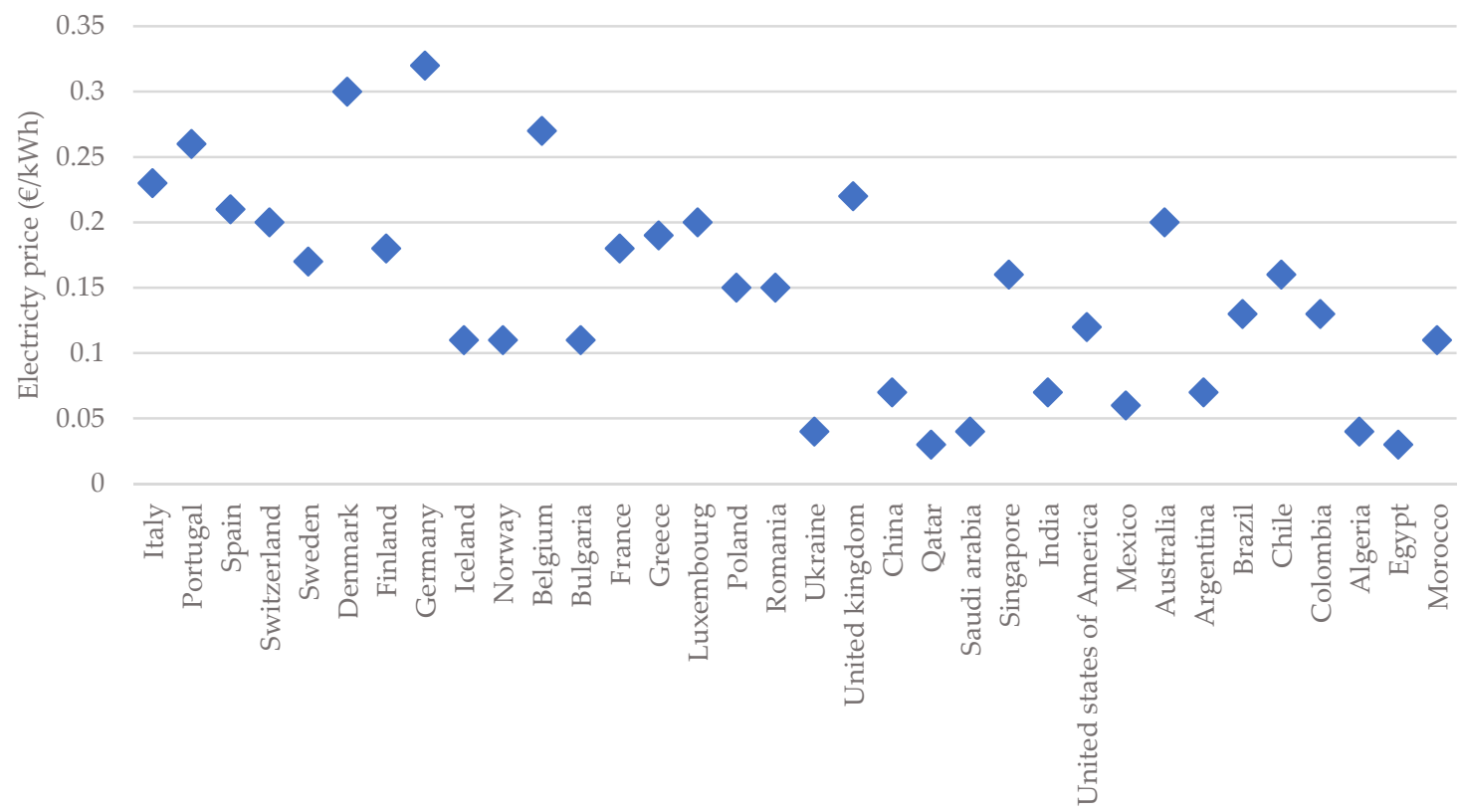

Figure 6. Considered electricity prices in all countries [37].

\section{Results and Discussion}

This section details the simulation results using the digital mapping approach. Table 5 shows the inputs and results of key performance indicators for all selected locations, and the results are discussed.

\subsection{Energy Performance Evaluation of PVT Panel}

\subsubsection{Collector Thermal Production}

The simulated results are visualized using geospatial maps, as they provide clear indication for understanding regional trends for thermal and electrical output even in the case of large datasets. Figure 7 shows the variation in the thermal output of the collector.

Annual average collector thermal production (kWh)

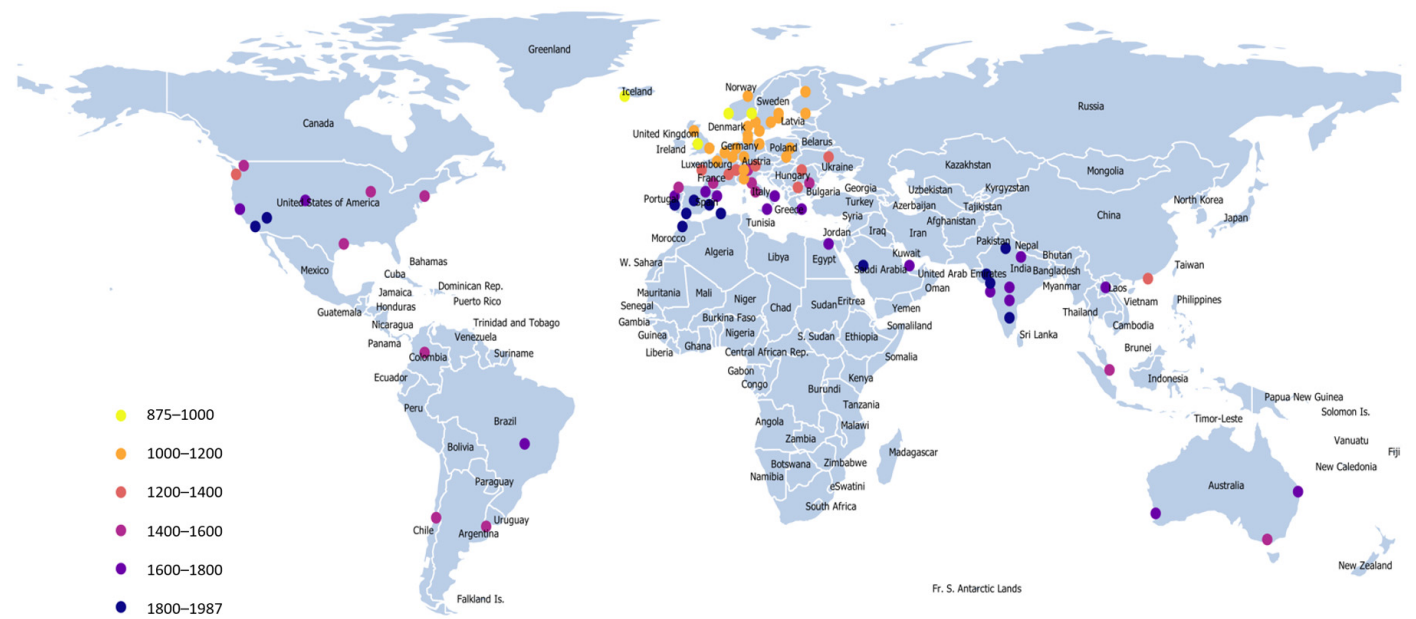

Figure 7. Annual average collector thermal performance. 
Table 5. All simulated data of key performance indicators.

\begin{tabular}{|c|c|c|c|c|c|c|c|c|}
\hline Country & City & Latitude & $\begin{array}{c}\text { Annual } \\
\text { GHI (kWh) }\end{array}$ & $\begin{array}{l}\text { Annual Average } \\
\text { Temperature }\left({ }^{\circ} \mathrm{C}\right)\end{array}$ & $\begin{array}{l}\text { Annual Thermal } \\
\text { Production (kWh) }\end{array}$ & $\begin{array}{l}\text { Annual Electrical } \\
\text { Production (kWh) }\end{array}$ & $\begin{array}{l}\text { NPV per Unit Collector } \\
\text { Area for Financial } \\
\text { Model } 1 \text { (EUR) }\end{array}$ & $\begin{array}{l}\text { NPV per Unit Collector } \\
\text { Area for Financial } \\
\text { Model } 2 \text { (EUR) }\end{array}$ \\
\hline \multirow{5}{*}{ Italy } & Catania & 38 & 1967 & 18 & 1790 & 487 & 5140 & 5541 \\
\hline & Florence & 44 & 1632 & 16 & 1520 & 413 & 4039 & 4451 \\
\hline & Milan & 45 & 1233 & 12 & 1153 & 317 & 2528 & 2955 \\
\hline & Rome & 42 & 1585 & 17 & 1464 & 401 & 3797 & 4211 \\
\hline & Bari & 41 & 1824 & 17 & 1679 & 458 & 4691 & 5096 \\
\hline \multirow{3}{*}{ Portugal } & Lisbon & 39 & 1939 & 18 & 1770 & 483 & 4766 & 5171 \\
\hline & Porto & 41 & 1765 & 16 & 1640 & 447 & 4246 & 4657 \\
\hline & Setubal & 39 & 1997 & 18 & 1823 & 495 & 4966 & 5368 \\
\hline \multirow{6}{*}{ Spain } & Sevilla & 37 & 2134 & 20 & 1882 & 520 & 4972 & 5361 \\
\hline & Valencia & 39 & 2043 & 18 & 1831 & 505 & 4776 & 5167 \\
\hline & Zaragoza & 42 & 2002 & 16 & 1795 & 498 & 4649 & 5041 \\
\hline & Barcelona & 41 & 1904 & 18 & 1728 & 479 & 4387 & 4782 \\
\hline & Lugo & 43 & 1567 & 13 & 1464 & 406 & 3393 & 3798 \\
\hline & Madrid & 40 & 2019 & 15 & 1810 & 504 & 4709 & 5101 \\
\hline \multirow{4}{*}{ Switzerland } & Bern & 47 & 1335 & 10 & 1270 & 351 & 2576 & 3002 \\
\hline & Davos & 47 & 1612 & 4 & 1562 & 426 & 2863 & 3286 \\
\hline & Lausanne & 47 & 1408 & 12 & 1329 & 364 & 2108 & 2539 \\
\hline & Zurich & 47 & 1249 & 10 & 1186 & 331 & 1648 & 1935 \\
\hline \multirow{5}{*}{ Sweden } & Gothenburg & 58 & 1138 & 10 & 1073 & 305 & 1287 & 1726 \\
\hline & Linkoping & 58 & 1132 & 8 & 1061 & 304 & 1257 & 1697 \\
\hline & Malmo & 56 & 1183 & 9 & 1113 & 316 & 1424 & 1863 \\
\hline & Stockholm & 59 & 1179 & 8 & 1105 & 317 & 1407 & 1846 \\
\hline & Uppsala & 60 & 1099 & 8 & 1024 & 297 & 1142 & 1583 \\
\hline \multirow{3}{*}{ Denmark } & Alborg & 57 & 1116 & 8 & 1047 & 298 & 3041 & 3463 \\
\hline & Copenhagen & 56 & 1144 & 10 & 1079 & 305 & 3195 & 3615 \\
\hline & Odense & 55 & 1102 & 9 & 1040 & 295 & 2987 & 3409 \\
\hline \multirow{2}{*}{ Finland } & Helsinki & 60 & 1160 & 6 & 1086 & 312 & 1021 & 1464 \\
\hline & Oulu & 65 & 1182 & 4 & 1112 & 321 & 1104 & 1545 \\
\hline
\end{tabular}


Table 5. Cont

\begin{tabular}{|c|c|c|c|c|c|c|c|c|}
\hline Country & City & Latitude & $\begin{array}{c}\text { Annual } \\
\text { GHI (kWh) }\end{array}$ & $\begin{array}{l}\text { Annual Average } \\
\text { Temperature }\left({ }^{\circ} \mathrm{C}\right)\end{array}$ & $\begin{array}{c}\text { Annual Thermal } \\
\text { Production (kWh) }\end{array}$ & $\begin{array}{l}\text { Annual Electrical } \\
\text { Production (kWh) }\end{array}$ & $\begin{array}{l}\text { NPV per Unit Collector } \\
\text { Area for Financial } \\
\text { Model } 1 \text { (EUR) }\end{array}$ & $\begin{array}{c}\text { NPV per Unit Collector } \\
\text { Area for Financial } \\
\text { Model } 2 \text { (EUR) }\end{array}$ \\
\hline \multirow{5}{*}{ Germany } & Berlin & 53 & 1194 & 10 & 1128 & 315 & 4582 & 4988 \\
\hline & Dortmund & 52 & 1093 & 11 & 1037 & 291 & 4034 & 4446 \\
\hline & Frankfurt & 50 & 1143 & 11 & 1078 & 302 & 4291 & 4701 \\
\hline & Hamburg & 54 & 1146 & 11 & 1091 & 306 & 4363 & 4772 \\
\hline & Munich & 48 & 1318 & 11 & 1257 & 345 & 5348 & 5747 \\
\hline Iceland & Reykjavik & 64 & 968 & 6 & 932 & 266 & -145 & 186 \\
\hline \multirow{3}{*}{ Norway } & Bergen & 60 & 926 & 9 & 875 & 253 & -576 & -163 \\
\hline & Oslo & 60 & 1029 & 7 & 962 & 277 & -408 & 3 \\
\hline & Trondheim & 64 & 1166 & 7 & 1107 & 317 & -136 & 273 \\
\hline Belgium & Brussels & 51 & 1151 & 12 & 1094 & 306 & 3244 & 3664 \\
\hline Bulgaria & Sofia & 43 & 1335 & 13 & 1264 & 348 & 364 & 813 \\
\hline \multirow{4}{*}{ France } & Lyon & 46 & 1422 & 14 & 1337 & 368 & 1899 & 2333 \\
\hline & Nantes & 47 & 1408 & 13 & 1333 & 367 & 1889 & 2323 \\
\hline & Paris & 49 & 1204 & 13 & 1134 & 315 & 1279 & 1718 \\
\hline & Toulouse & 44 & 1522 & 15 & 1437 & 391 & 2197 & 2628 \\
\hline Greece & Athinai & 38 & 1915 & 21 & 1731 & 474 & 3119 & 3540 \\
\hline Luxembourg & Luxembourg & 50 & 1194 & 9 & 1128 & 318 & 1661 & 2096 \\
\hline \multirow{2}{*}{ Poland } & Krakow & 50 & 1191 & 10 & 1126 & 315 & 868 & 1267 \\
\hline & Warsaw & 52 & 1213 & 10 & 1137 & 320 & 909 & 1307 \\
\hline \multirow{2}{*}{ Romania } & Bucharest & 44 & 1589 & 13 & 1482 & 406 & 1841 & 2153 \\
\hline & Cluj-Napoca & 47 & 1443 & 11 & 1365 & 374 & 1516 & 1831 \\
\hline Ukraine & Kyiv & 50 & 1330 & 10 & 1242 & 348 & -1287 & -1368 \\
\hline \multirow{3}{*}{$\begin{array}{l}\text { United } \\
\text { Kingdom }\end{array}$} & Glasgow & 56 & 1097 & 10 & 1045 & 294 & 2096 & 2527 \\
\hline & Liverpool & 53 & 1013 & 11 & 965 & 273 & 1765 & 2199 \\
\hline & London & 52 & 1107 & 13 & 1048 & 294 & 2109 & 2540 \\
\hline China & Hong Kong & 22 & 1338 & 24 & 1251 & 329 & 461 & 725 \\
\hline Qatar & Doha & 25 & 1957 & 28 & 1715 & 462 & -1468 & -1168 \\
\hline Saudi Arabia & Medina & 25 & 2349 & 29 & 1966 & 540 & -828 & -401 \\
\hline Singapore & Singapore & 1 & 1618 & 27 & 1473 & 390 & 1461 & 1569 \\
\hline
\end{tabular}


Table 5. Cont

\begin{tabular}{|c|c|c|c|c|c|c|c|c|}
\hline Country & City & Latitude & $\begin{array}{c}\text { Annual } \\
\text { GHI (kWh) }\end{array}$ & $\begin{array}{l}\text { Annual Average } \\
\text { Temperature }\left({ }^{\circ} \mathrm{C}\right)\end{array}$ & $\begin{array}{l}\text { Annual Thermal } \\
\text { Production (kWh) }\end{array}$ & $\begin{array}{l}\text { Annual Electrical } \\
\text { Production (kWh) }\end{array}$ & $\begin{array}{l}\text { NPV per Unit Collector } \\
\text { Area for Financial } \\
\text { Model } 1 \text { (EUR) }\end{array}$ & $\begin{array}{l}\text { NPV per Unit Collector } \\
\text { Area for Financial } \\
\text { Model } 2 \text { (EUR) }\end{array}$ \\
\hline \multirow{8}{*}{ India } & Bangalore & 13 & 2093 & 25 & 1847 & 489 & -12 & 178 \\
\hline & Bombay & 19 & 1910 & 28 & 1687 & 445 & -213 & -21 \\
\hline & Hyderabad & 17 & 2005 & 28 & 1765 & 466 & -112 & 79 \\
\hline & Lucknow & 27 & 1921 & 27 & 1717 & 453 & -174 & 17 \\
\hline & New Delhi & 29 & 2157 & 27 & 1878 & 505 & 35 & 224 \\
\hline & Surat & 21 & 2168 & 28 & 1874 & 500 & 26 & 215 \\
\hline & Wadhwan & 23 & 2159 & 28 & 1866 & 496 & 17 & 207 \\
\hline & Yavatmal & 20 & 1938 & 28 & 1715 & 453 & -179 & 13 \\
\hline \multirow{9}{*}{ USA } & Chicago & 42 & 1564 & 11 & 1475 & 402 & 987 & 1432 \\
\hline & Denver & 40 & 1912 & 11 & 1796 & 483 & 1695 & 2133 \\
\hline & Houston & 30 & 1720 & 21 & 1582 & 422 & 1211 & 1655 \\
\hline & Las Vegas & 36 & 2278 & 21 & 1987 & 545 & 2136 & 2570 \\
\hline & Los Angeles & 34 & 1973 & 20 & 1808 & 489 & 1722 & 2161 \\
\hline & New York & 41 & 1597 & 14 & 1508 & 407 & 1052 & 1496 \\
\hline & Portland & 46 & 1436 & 12 & 1361 & 374 & 732 & 1179 \\
\hline & $\begin{array}{c}\text { San } \\
\text { Francisco }\end{array}$ & 38 & 1886 & 15 & 1757 & 478 & 1616 & 2056 \\
\hline & Washington & 39 & 1602 & 15 & 1510 & 407 & 1053 & 1497 \\
\hline Mexico & Mexico City & 20 & 1848 & 18 & 1727 & 451 & -342 & -224 \\
\hline \multirow{3}{*}{ Australia } & Brisbane & -27 & 1898 & 21 & 1720 & 452 & 3940 & 4339 \\
\hline & Melbourne & -38 & 1528 & 15 & 1426 & 371 & 2872 & 3282 \\
\hline & Perth & -32 & 1930 & 19 & 1731 & 455 & 3990 & 4389 \\
\hline Argentina & $\begin{array}{c}\text { Buenos } \\
\text { Aires }\end{array}$ & -35 & 1703 & 18 & 1550 & 406 & 65 & -2077 \\
\hline Brazil & Brasilia & -16 & 1928 & 22 & 1762 & 467 & 1985 & 2197 \\
\hline Chile & Santiago & -33 & 1732 & 15 & 1570 & 411 & 1785 & 2171 \\
\hline Colombia & Bogota & 5 & 1560 & 14 & 1510 & 394 & 856 & 1107 \\
\hline Algeria & Algiers & 37 & 2017 & 18 & 1835 & 495 & -1027 & -747 \\
\hline Egypt & Cairo & 30 & 2009 & 22 & 1791 & 485 & -1551 & -1589 \\
\hline Morocco & Rabat & 34 & 2094 & 18 & 1907 & 517 & 1616 & 1950 \\
\hline
\end{tabular}


The general trend shows that thermal output is higher in countries with higher irradiation, such as Saudi Arabia, Algeria, Morocco, Brazil, Mexico, India, etc., with annual thermal production above $1800 \mathrm{kWh}$ (area-specific output $918 \mathrm{kWh} / \mathrm{m}^{2}$ ) due to high GHI and ambient temperatures. The lower band of average collector production can be seen in Reykjavik, Iceland, and for some locations in Norway, with a specific output of 475 and $500 \mathrm{kWh} / \mathrm{m}^{2}$, respectively. Similar thermal output is obtained for locations in countries such as Sweden, Finland, United Kingdom, Denmark, etc., with less than $510 \mathrm{kWh} / \mathrm{m}^{2}$ annual production. The collector shows better performance in countries, such as Spain, Portugal, and Australia, with collector production of above $1600 \mathrm{kWh}\left(816 \mathrm{kWh} / \mathrm{m}^{2}\right)$.

Figure 8 shows the correlation of collector thermal production with GHI and ambient temperature. All the simulated data points of these parameters are considered to define the possible trend. Results show that thermal output has a strong linear correlation with GHI with $\mathrm{R}^{2}$ value close to 0.98 . Thus, the location with higher GHI has higher thermal output. In addition, thermal output shows a linear trend with ambient temperature for most of the data points, however, the correlation is not as strong as with GHI. Therefore, ambient temperature cannot be used as a sole indicator to estimate the collector output.

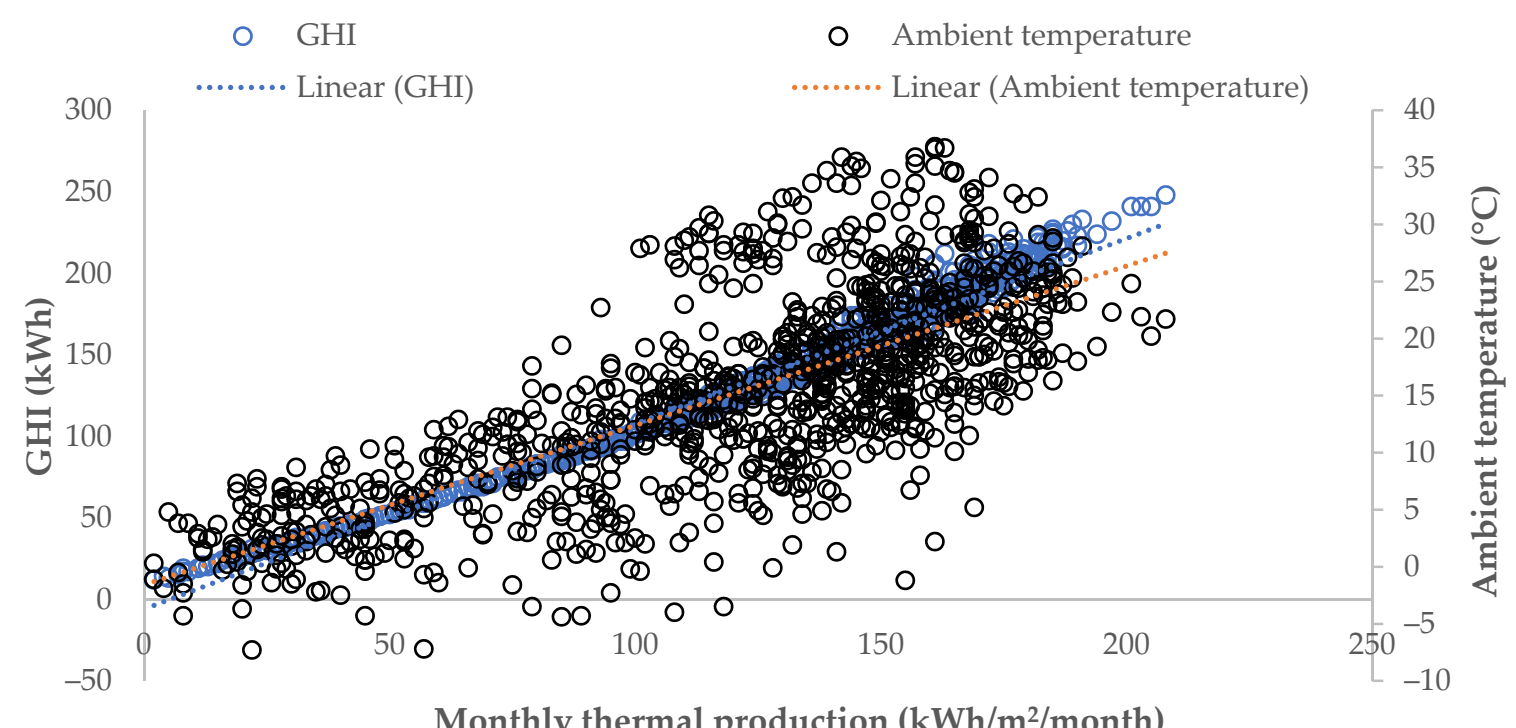

Figure 8. Correlation of collector thermal production with global horizontal irradiation (GHI) and ambient temperature.

\subsubsection{Collector Electrical Production}

Figure 9 represents the electrical performance of the collector, which shows similar trends as thermal output. For locations in countries with high GHI, such as Saudi Arabia, Algeria, Morocco, Brazil, India, etc., generation is above $500 \mathrm{kWh}$, and the peak value is in Saudi Arabia with $540 \mathrm{kWh}$. The electrical production is much less in Iceland with $266 \mathrm{kWh}$ due to less available GHI, and the collector generation is lower than $300 \mathrm{kWh}$ in Sweden, Finland, Denmark, Poland, United Kingdom, etc. The collector performed slightly better in Spain, Portugal, and Australia, with more than $400 \mathrm{kWh}$ annually. However, it shows there is no significant difference in thermal and electrical production trends. Furthermore, a correlation of collector electrical production with GHI and ambient temperature is developed based on all monthly points from all chosen locations and a positive correlation is realized as shown in Figure 10. A large variation in electrical output for similar values of ambient temperature can be observed, which again shows that GHI is the critical parameter governing the electrical output of the collector. 
Annual average collector electrical production $(\mathrm{kWh})$

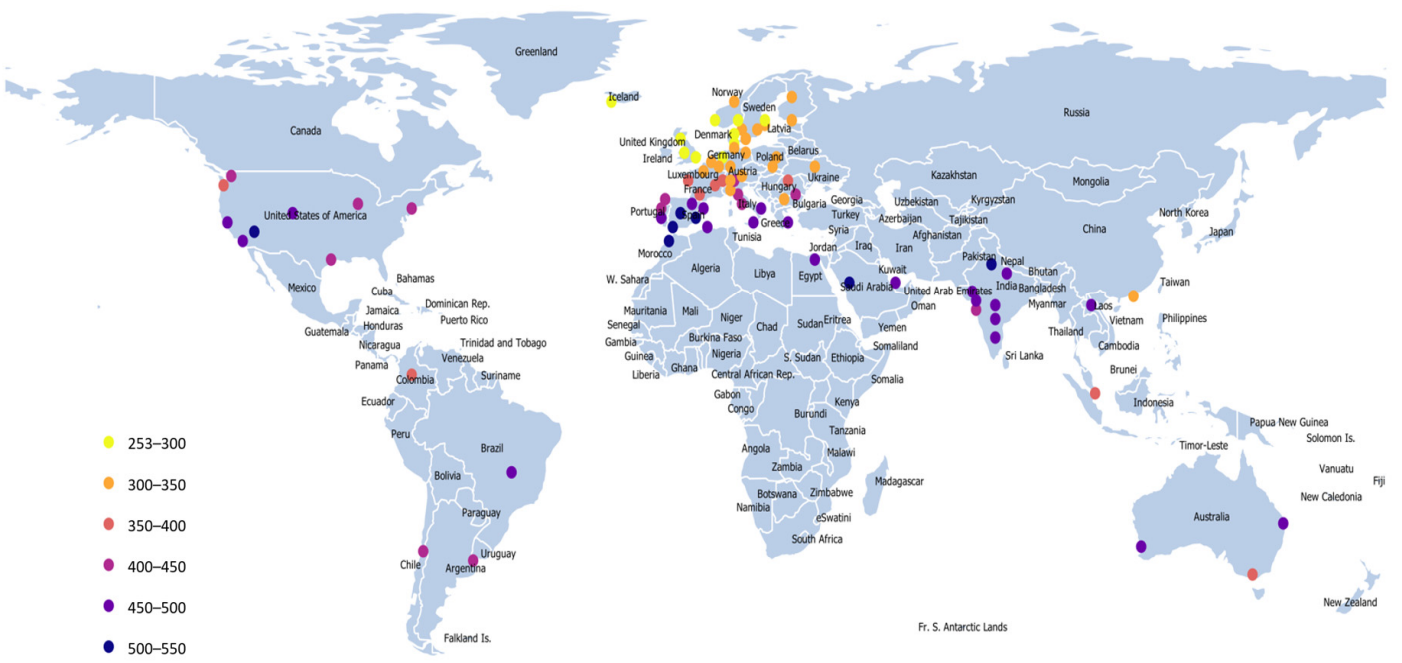

Figure 9. Annual average collector electrical performance.

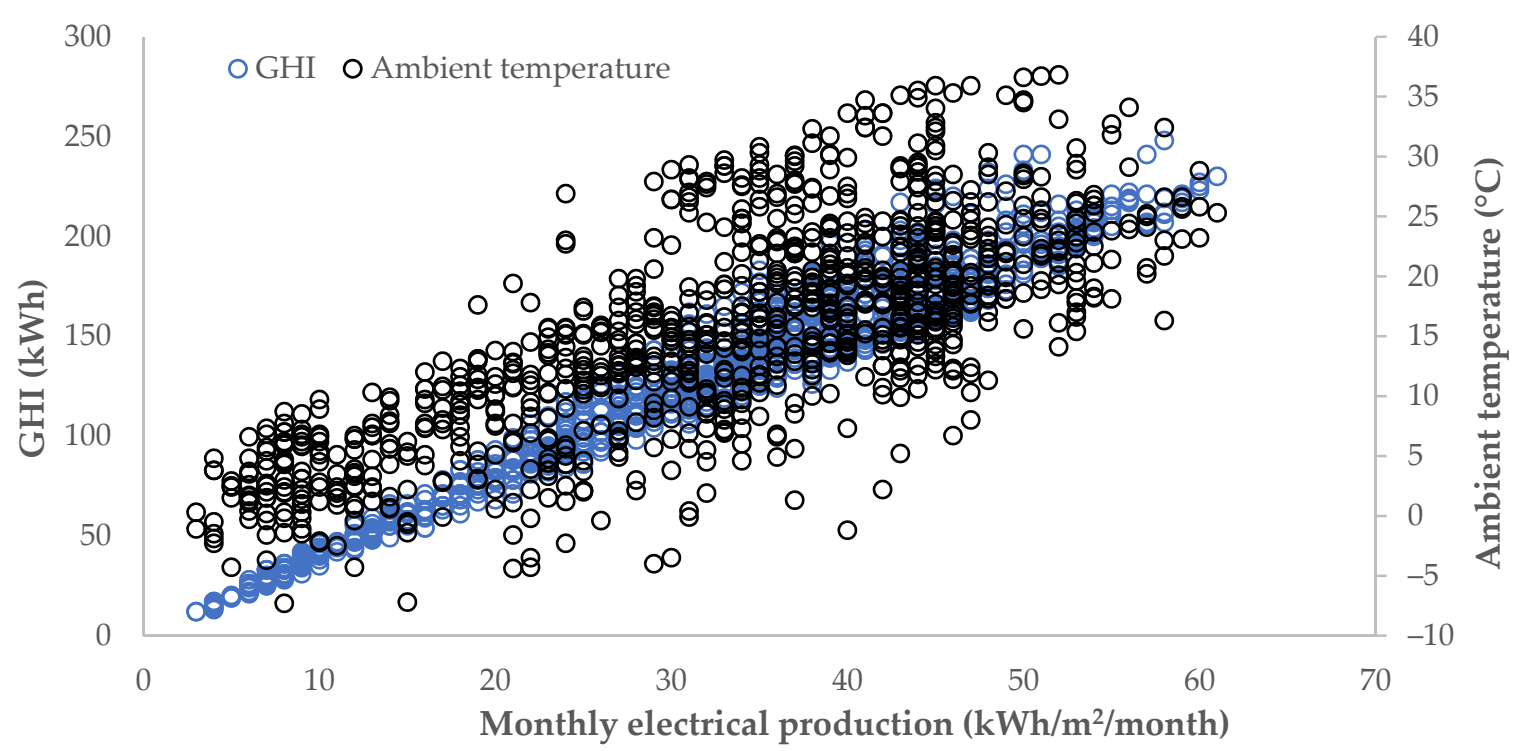

Figure 10. Correlation of collector electrical production with global horizontal irradiation (GHI) and ambient temperature.

A large variation in thermal and electrical output is seen for many countries and is reflected in Figures 7 and 9. The range of collector output with a maximum and minimum value of thermal and electrical production is shown in Figure 11.

The minimum thermal production in blue color represents the minimum production for analyzed location, while the maximum thermal production is indicated with an orange color that represents the highest thermal production of a city in each country. The results show likely high variation in Italy, Spain, United States, and Australia, as many cities were simulated in those countries, and less variation is recorded in countries Denmark, Iceland, United Kingdom, etc., due to the lower number of simulated cities.

In general, PVT collector monthly production is an important key factor in the sizing of a solar system to match the monthly variation of energy consumption. Figures 12 and 13 show the variation in collector monthly thermal and electrical production, respectively. The thermal performance in April and July is relatively higher and less in January and October for the locations in the northern hemisphere, 
such as Madrid, Stockholm, and Berlin. In Medina, although GHI and ambient temperatures are higher in July, the thermal production is lower compared to in October. This is because the thermal demand in July is less than in October. Therefore, in July, due to high GHI and less thermal demand, the storage tank losses will be higher as the tank temperature increases. Higher tank temperature results in lower thermal and electrical production of collector. As the GHI trend in the southern hemisphere is opposite to the northern hemisphere, the production in January and October is likely higher than the April and July months. In Stockholm, the variation between the months is significant because of seasonal variation in GHI, and the same is lower in Medina, which results in more uniform monthly production.

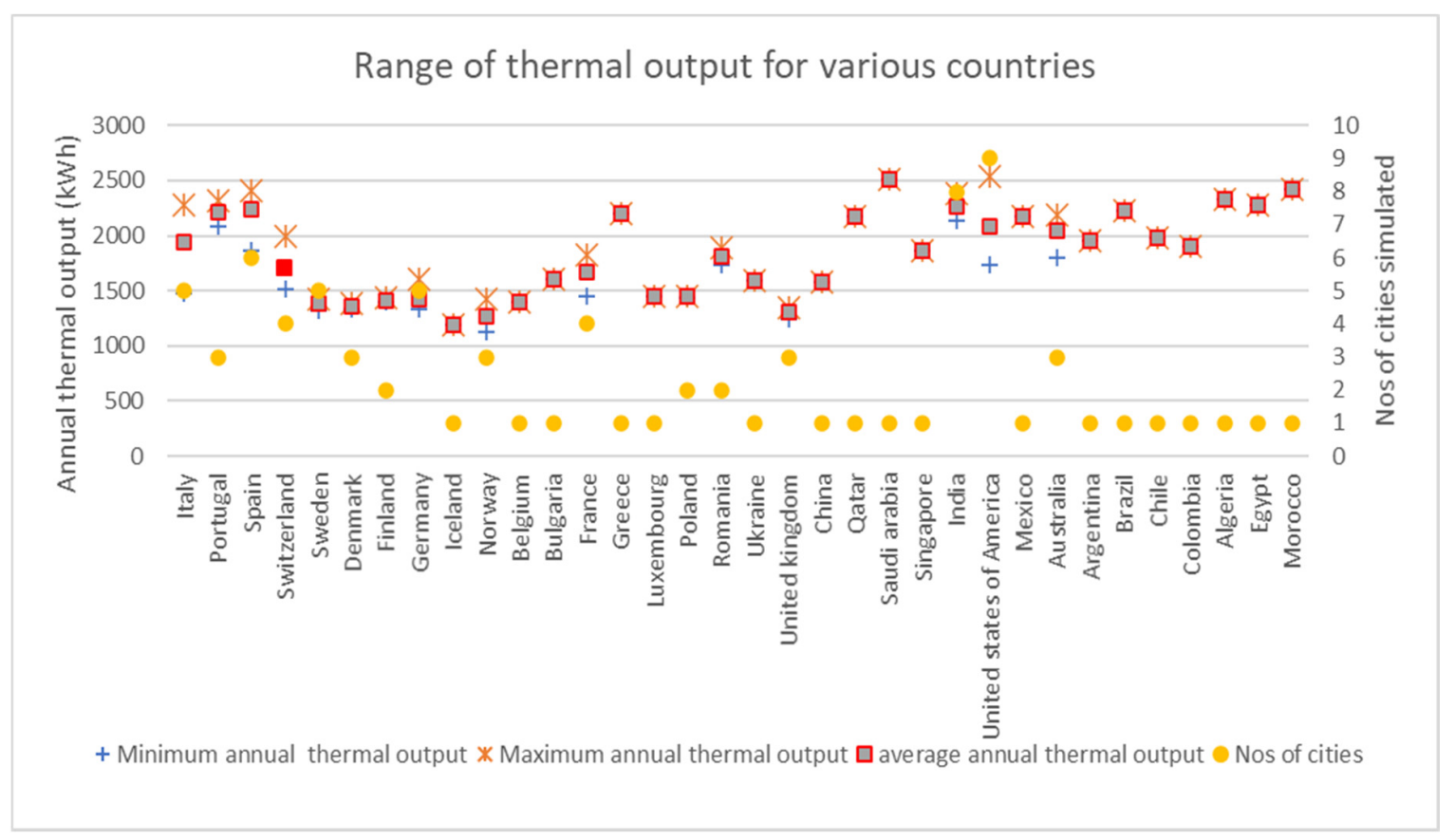

Figure 11. Country-wise collector thermal performance uncertainty.

The trends for monthly electrical production are slightly different than thermal output. For example, in Medina, electrical production is higher in July than in October even though the ambient temperature is maximum in July. This is due to high GHI in July and is in line with findings that the major factor influencing the electrical production is GHI, rather than ambient temperature.

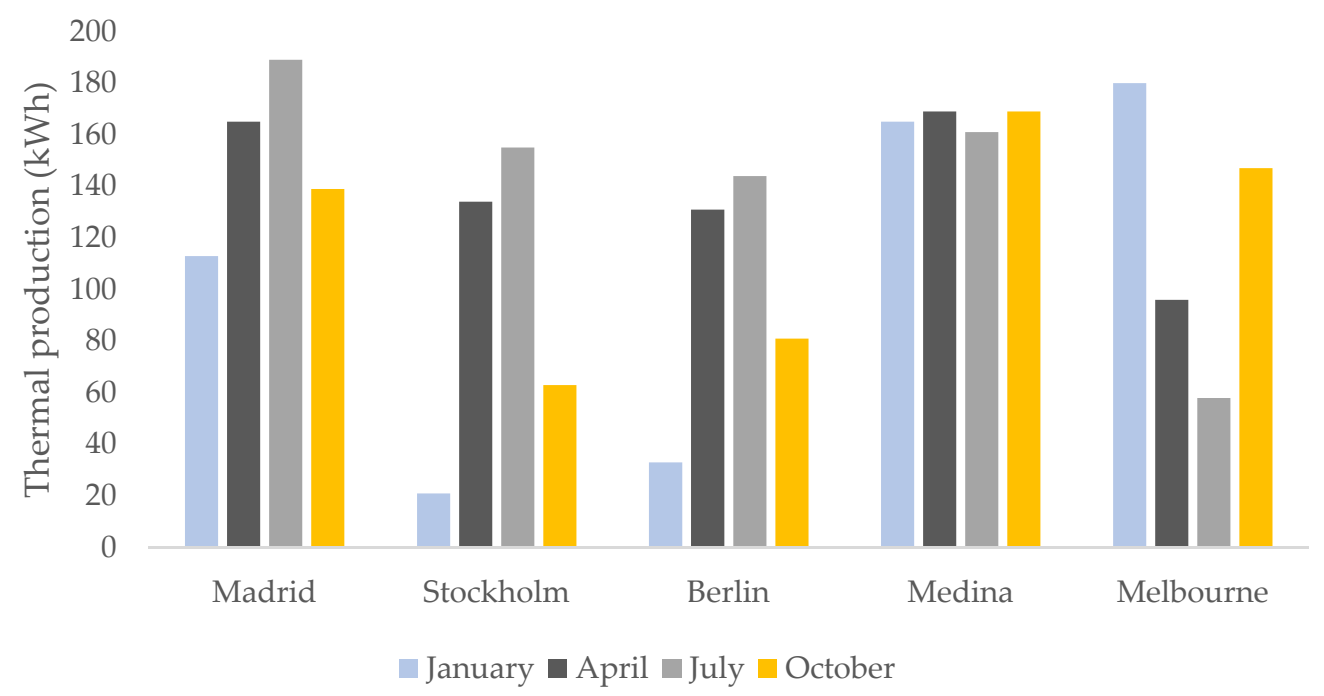

Figure 12. Collector monthly thermal production variation. 


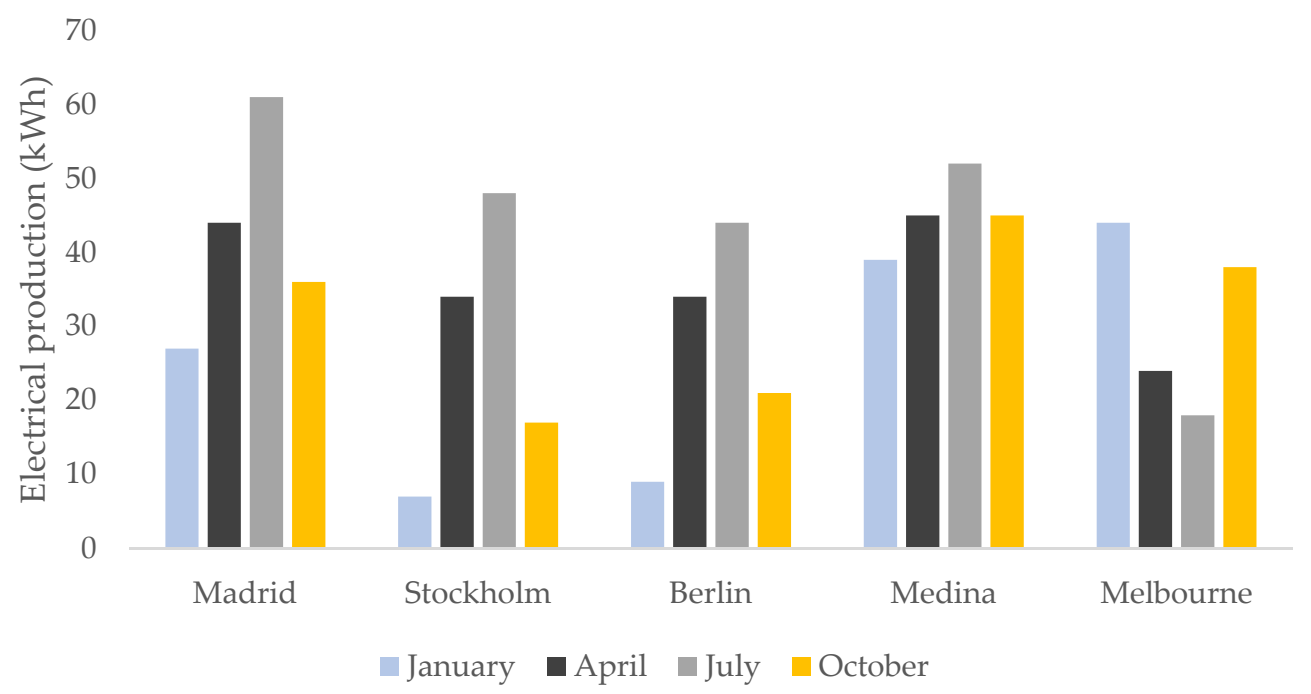

Figure 13. Collector monthly electrical production variation.

\subsubsection{Collector Energy Utilization Ratio}

The energy utilization ratio of the collector for various locations is shown in Figure 14. The correlation trends between energy utilization ratio and annual average ambient temperature are shown in Figure 15 with consideration of all selected 85 geographical locations to derive a possible trend between the parameters.

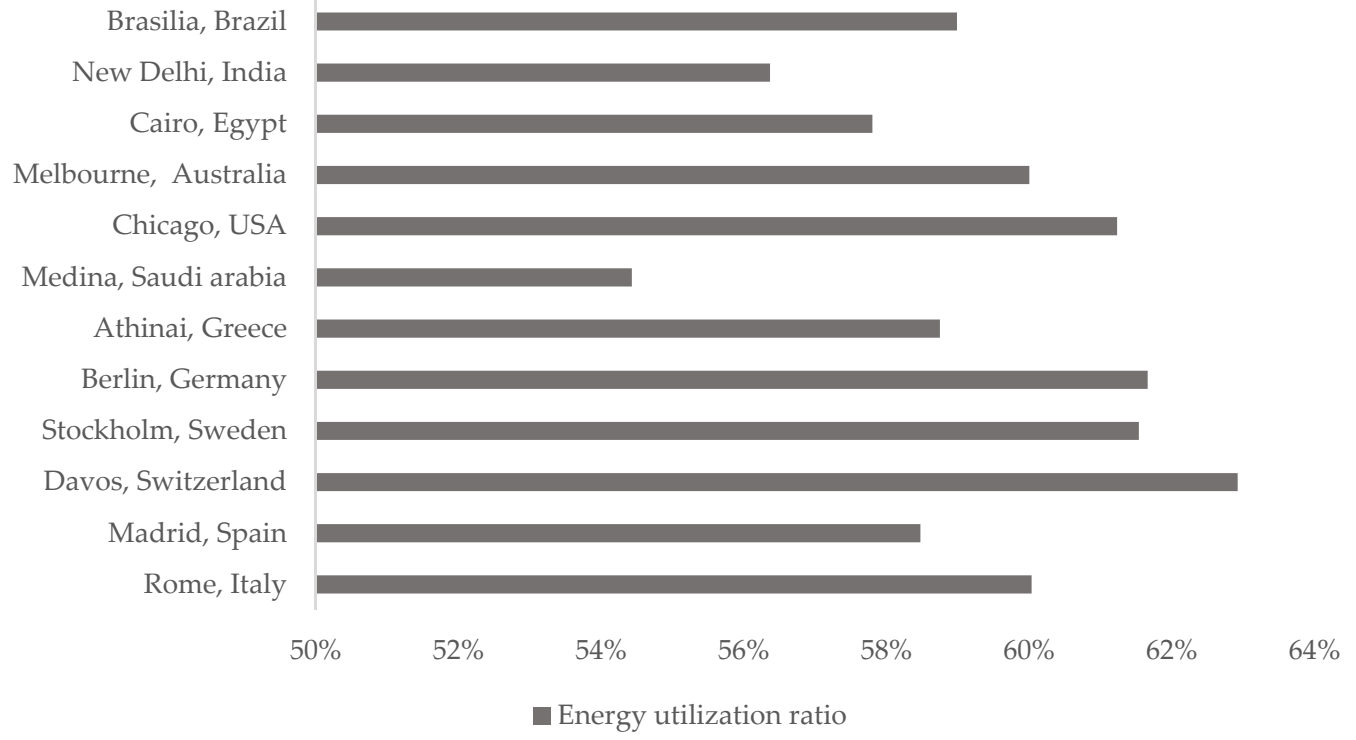

Figure 14. Collector energy utilization ratio.

Some locations show interesting results of system boundaries on PVT collector performance. This can be realized by comparing the energy utilization ratio for Medina (high irradiation) and Davos (low irradiation location). The energy utilization for Davos (63\%) is higher compared to Medina (52.5\%), even though the absolute value of total energy output is higher for Medina (2506 kWh) compared to Davos (1988 kWh). This is because the load demand for Medina is comparably lower, while the other system design parameters remain the same (collector area, tank volume, etc.), which resulted in higher average tank temp and thus lower collector efficiency for Medina. Results show that the total thermal demand for every location varies depending on the ambient temperature as shown in Figure 16. This is because of the temperature difference between the annual average ambient temperature of each 
location and desired water temperature (assumed $60^{\circ} \mathrm{C}$ ), which has to be covered by the collector thermal production.

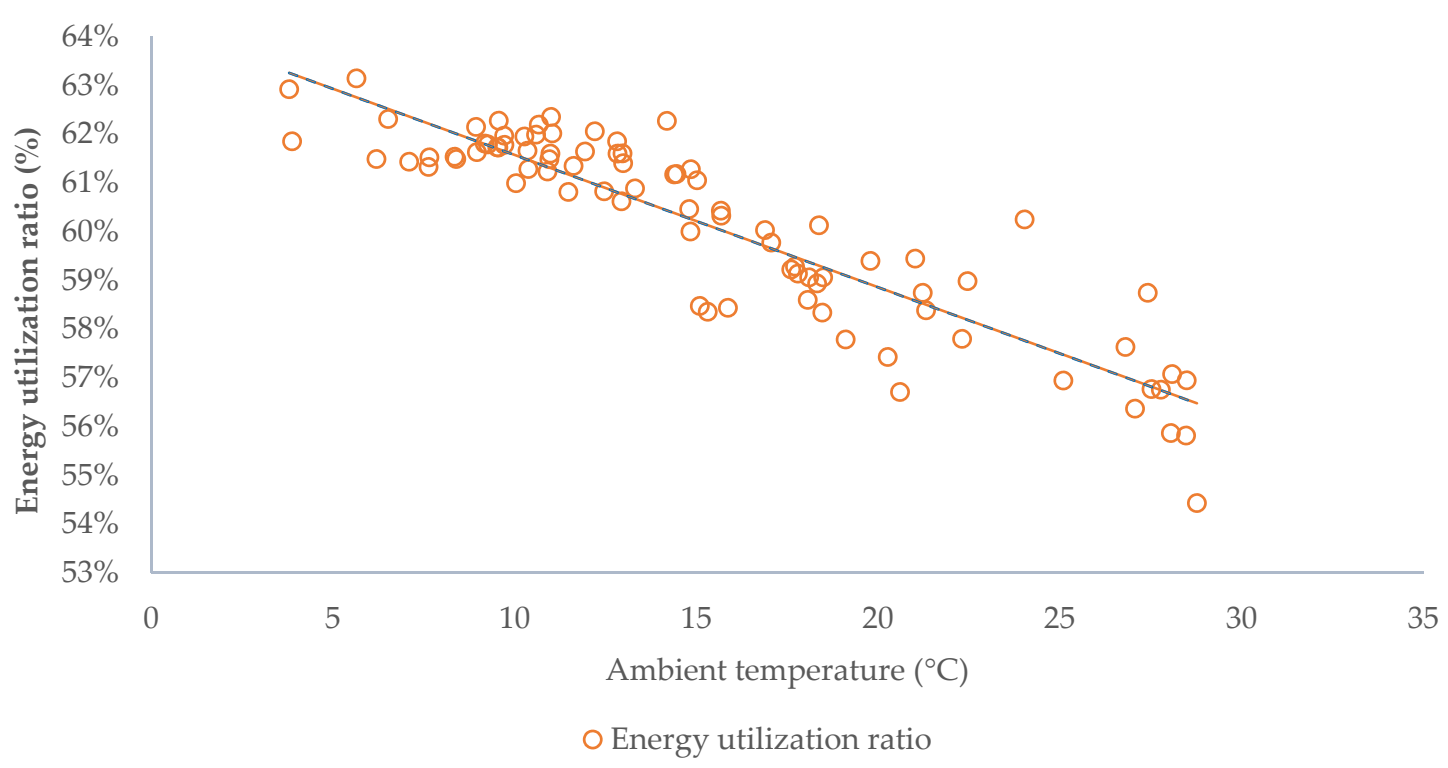

Figure 15. Correlation of energy utilization ratio with the annual average ambient temperature.

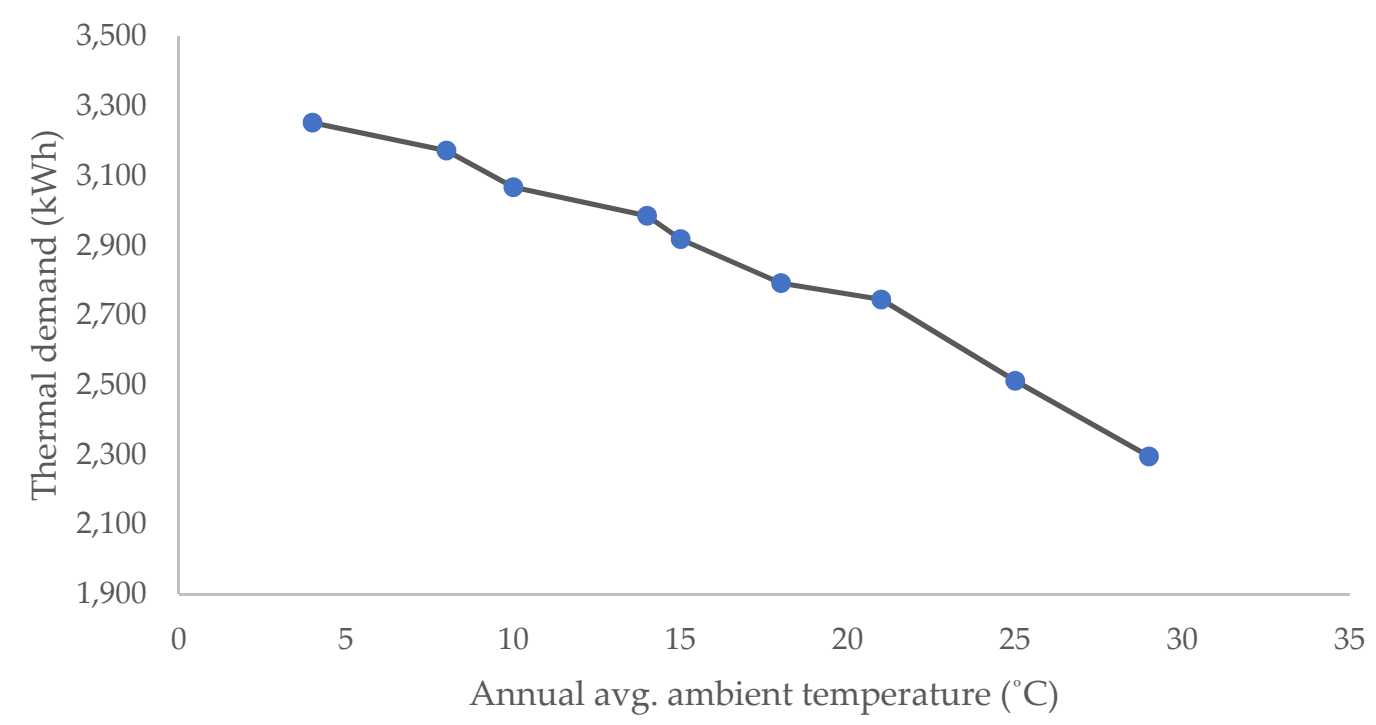

Figure 16. Total thermal demand of single-family house relation with the average ambient temperature.

\subsubsection{Collector Exergy Efficiency}

From the Carnot efficiency, it can be noted that exergy efficiency is a function of inlet temperature and thermal output of the collector (assumed that the desired output temperature is fixed at $60^{\circ} \mathrm{C}$ ). Hence, it can be derived that locations with higher ambient temperature will result in less quality of exergy and, thus, lower exergetic efficiency.

Figure 17 shows the correlation of exergetic efficiency with ambient temperature based on all selected 85 geographical locations to derive a possible trend between the parameters. Similar trends can be seen for some specific locations shown in Figure 18. It can be seen that even though the energy efficiency of Madrid is higher compared to Davos, the exergy efficiency of Davos is higher due to lower annual ambient temperature and, thus, higher quality of heat is delivered to the user. 


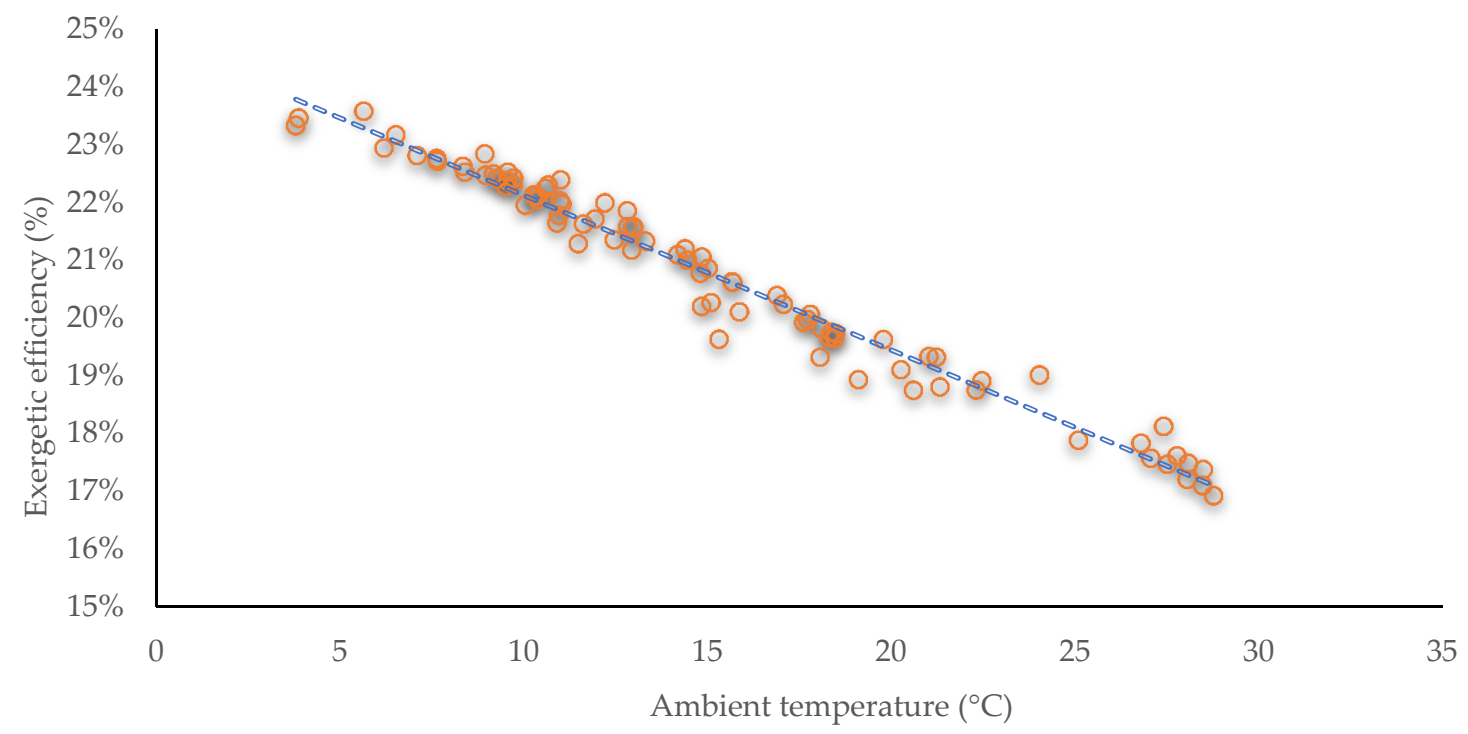

Figure 17. Correlation of exergy efficiency with the annual average ambient temperature.

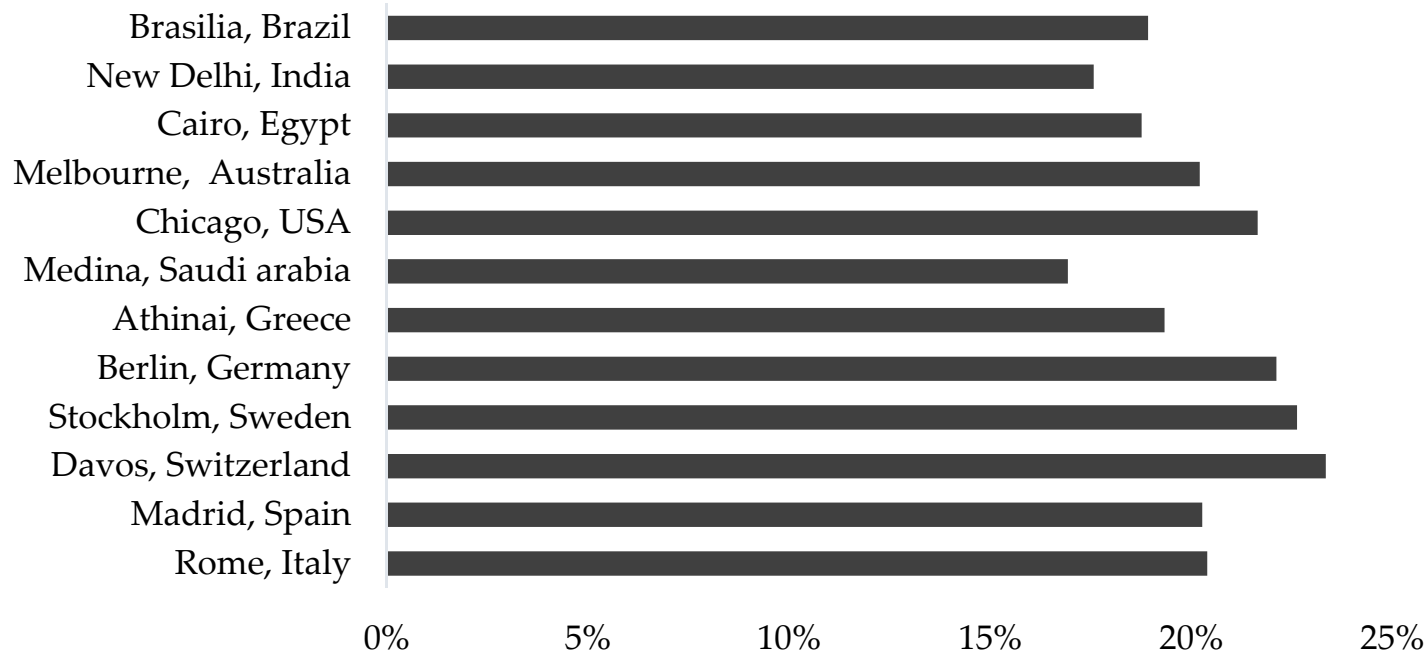

Figure 18. Collector exegetic efficiency.

\subsection{Economic Performance Evaluation of the PVT Collector}

Based on the above energy performance, the economic performance of such a PVT system is investigated in the 85 different locations. In this section, the NPV per unit collector area is analyzed and represented.

\subsubsection{Collector Economic Performance in Financing Model 1}

This financing model scenario has assumed that the total cost of the system is invested in the first year of the system period. As the total system cost will be invested in the first year, the interest rate is not considered. Figure 19 is the digital representation of NPV potential per unit collector area with financial model 1 in all 85 geographical cities across the world and Figure 20 shows the NPV potential per unit collector area in geographical cities in the European continent. 


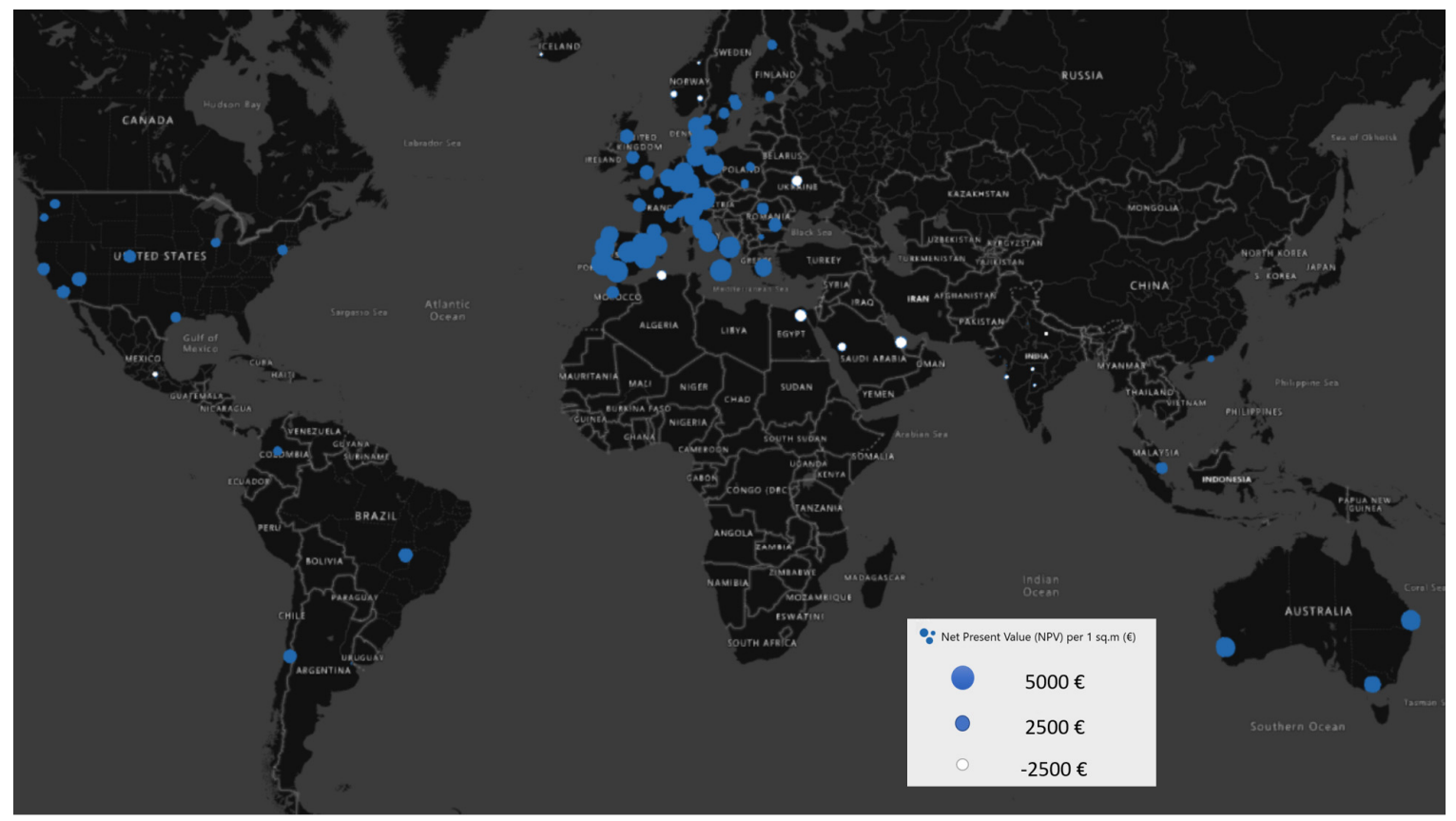

Figure 19. Net present value (NPV) potential per unit collector area for financing model 1.

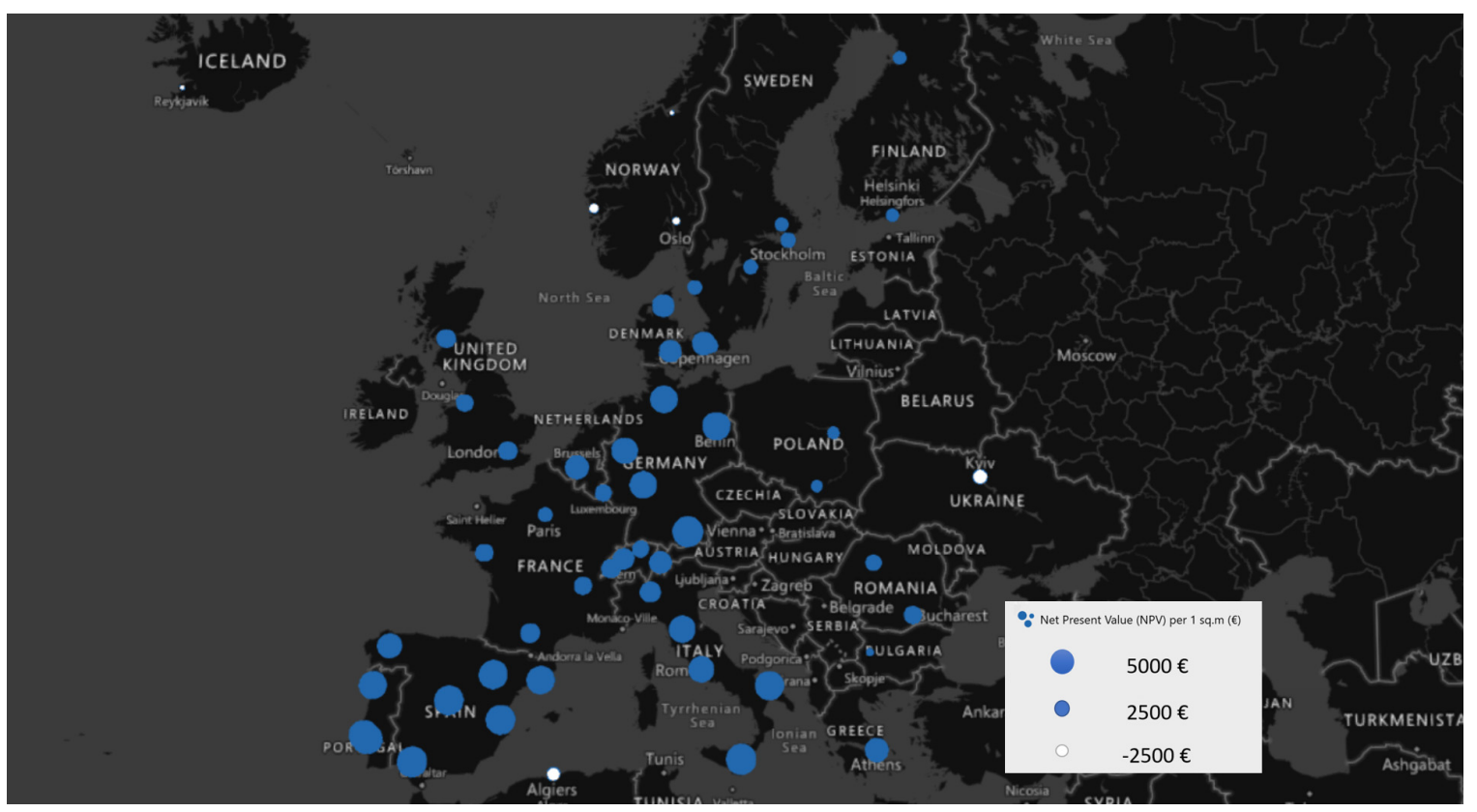

Figure 20. NPV potential per unit collector area in Europe for financing model 1.

The cities with larger dots represent the high NPV potential and cities with smaller dots size represents the least NPV potential. The cities Catania and Munich have the highest potential of 5140 and 5348 EUR, respectively, followed by the cities Bari, Lisbon, Setubal, Sevilla, Valencia, Zaragoza, Madrid, and Berlin, which have potentially more than 4500 EUR per unit collector area. This is due to their high available GHI and electricity grid price, so the energy savings are high in these locations which is reflected in huge NPV potential for this system. Cities such as Oslo, Bergen, Reykjavik, etc., with relatively less electricity grid price resulted in having negative NPV due to lower available GHI. The cities with high collector production such as Medina, Algeria, and Cairo have shown negative NPV potential due to a much lower electricity grid price which eventually showed fewer energy savings. 
The NPV potential in all 85 simulated cities has been selected, divided, and segmented for the appropriate countries to define the NPV range per unit collector area of each country as shown in Figure 21. A large variation in NPV can be seen in a few countries, such as Italy and Portugal, due to variability in GHI for simulated locations. However, a smaller variation is identified in countries such as China, Argentina, Brazil, etc., because only one city has been simulated in this paper, which is part of the key uncertainty.

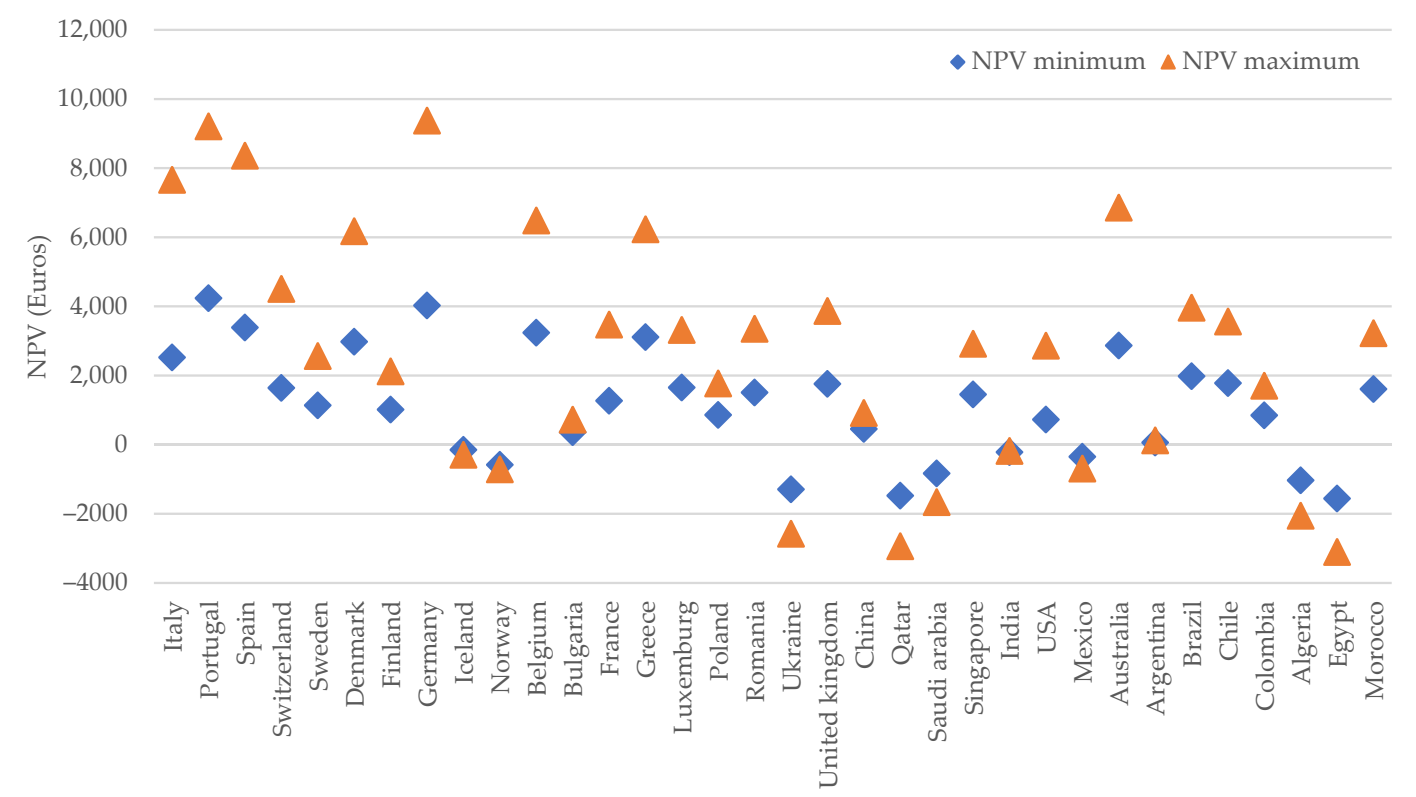

Figure 21. Country-wise NPV potential per unit collector area for financial model 1.

Figure 22 shows the payback period of this PVT system for a single-family house of 5 people in several countries based on financial model 1. The results show that the total system cost will be returned in the first 10 years in countries such as Australia, Belgium, Denmark, Germany, Greece, Italy, Portugal, Spain, Switzerland, etc. This is due to high collector production and high electricity grid price. Although countries such as Algeria, Saudi Arabia, and Egypt have the highest collector production, the grid price is comparatively lower, which reflects the payback period of more than 20 years.

Payback Period (Years)

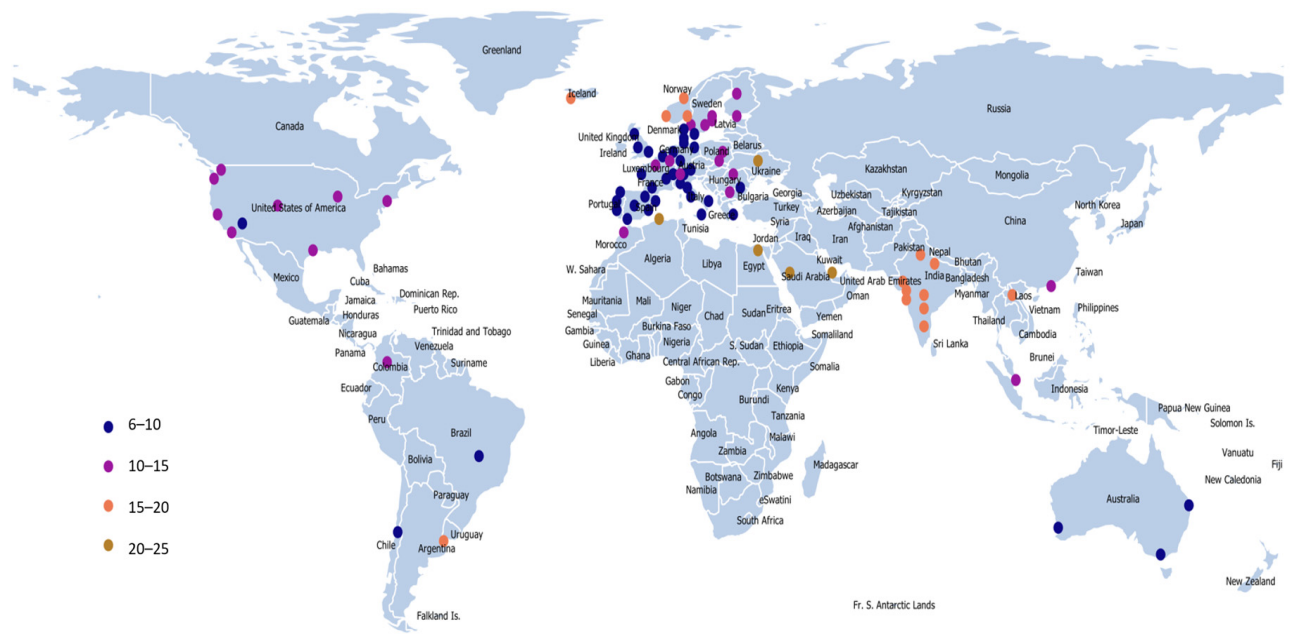

Figure 22. Country-wise average payback period of the PVT collector system. 


\subsubsection{Collector Economic Performance in Financing Model 2}

This financing model has been analyzed by assuming that $75 \%$ of total system cost is paid within a financing period of 7 years with a certain interest rate and that the remaining $25 \%$ of total system cost is invested in the first year without any interest rate. The NPV potential per unit collector area with financing model 2 in 85 geographical cities across the world is shown in Figure 23, and NPV potential per unit collector area in a specific European continent is shown in Figure 24.

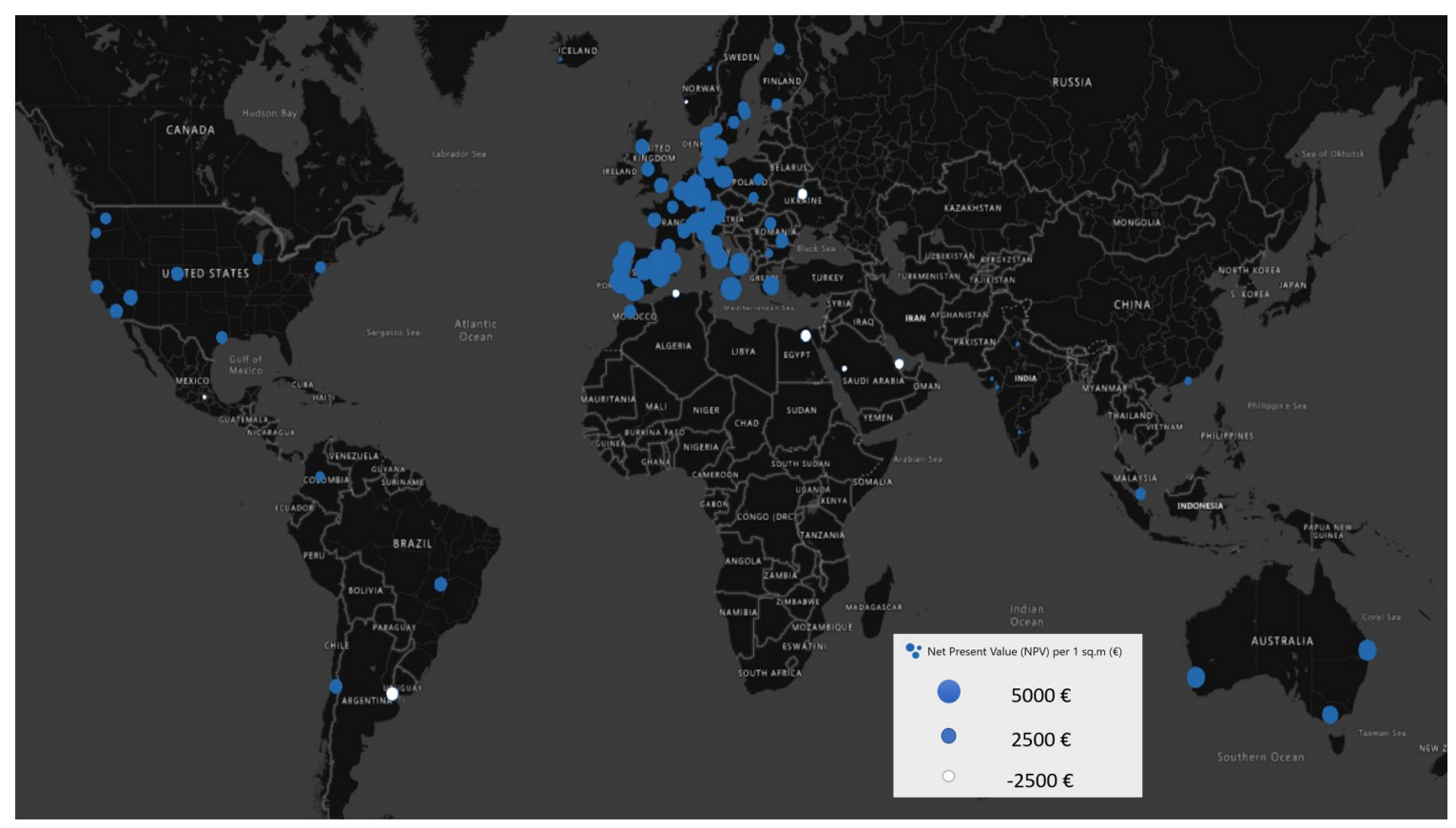

Figure 23. NPV potential per unit collector area for financing model 2.

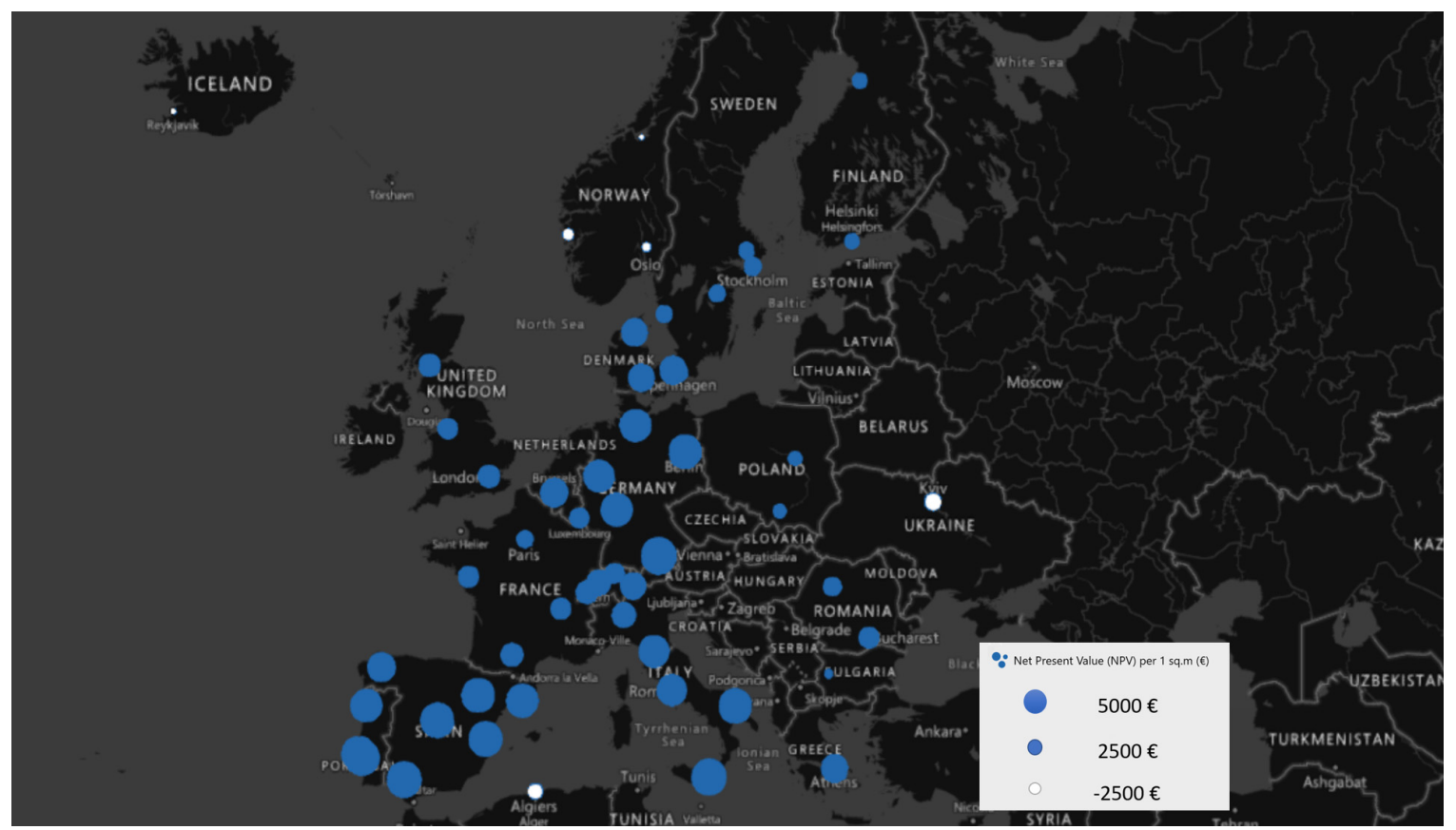

Figure 24. NPV potential per unit collector area in Europe for financing model 2. 
The cities with larger dots represent the high NPV potential cities and those with smaller dots represent the lower NPV potential. The cities that showed high NPV potential in financing model 1, such as Catania and Munich, which have shown improved NPV of 5140 and 5348 EUR, respectively, were because of the almost zero interest rates in those countries. This is because if the interest rate is zero, the user needs to pay part of the system cost in later years, and the present value of this investment will be lower due to the time value of money. This will reduce the accumulated investment and thus higher NPV. However, if the interest rate is high, the extra amount paid due to high interest in later years will overweigh the advantage due to the time value of money, and it will decrease the overall NPV. Therefore, financial model 1 is recommended for countries with a high interest rate to maximize the NPV and minimize the payback. Meanwhile, financial model 2 is recommended for countries with zero or lower interest rates to maximize the NPV.

Figure 25 shows the NPV potential per unit collector area in each country for the financing model 2. As compared with financing model 1, there is slightly better performance in NPV in most of the countries. Thus, not much variation has been identified in model 2 compared with model 1 .

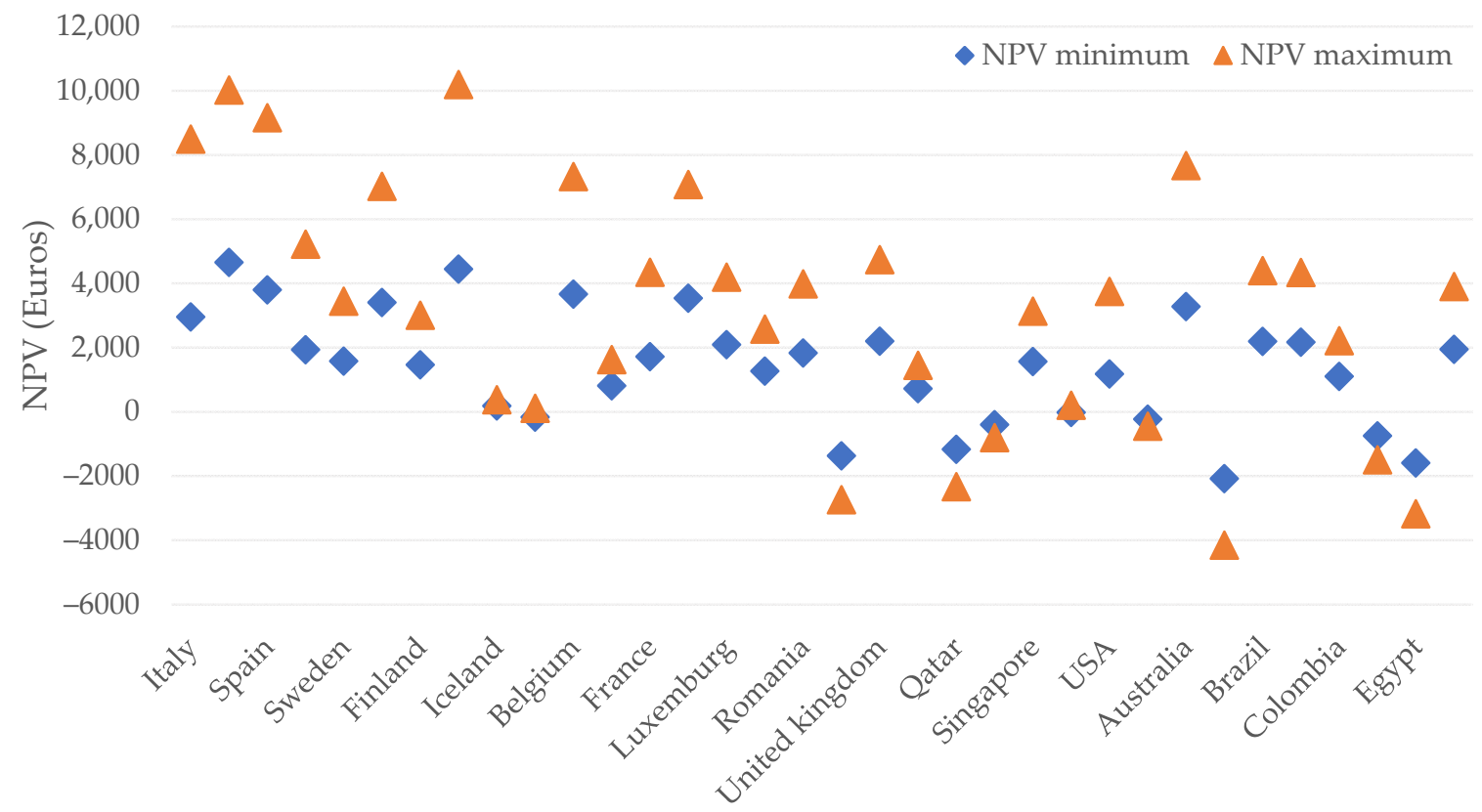

Figure 25. Country-wise NPV potential per unit collector area for financing model 2.

The effect of NPV change due to financial model 2 compared to model 1 is shown in Figure 26. As expected, the countries with high interest rate have shown a negative effect on NPV and countries with less and zero interest rates have shown better NPV potential, such as United States, Australia, and most of the European countries. However, due to the high interest rate of $38 \%$ in Argentina, a huge negative impact is identified with financing model 2. Furthermore, a correlation is derived between NPV variations with an interest rate of a specific location in Figure 27.

\subsection{Uncertainties}

In this paper, the authors acknowledge the possible uncertainties in energy performance analysis. For instance, the delivery water temperature is assumed to be $60{ }^{\circ} \mathrm{C}$ and $28 \mathrm{~L}$ DHW demand per person for all locations across all cities. In addition, the specific volume ratio (v/a) has been assumed as $80 \mathrm{~L} / \mathrm{m}^{2}$ for all locations, but since it may vary depending on the location and type of application, the resulted collector production would be slightly different in real time, but this approach has been assumed to achieve the goals of this paper. 


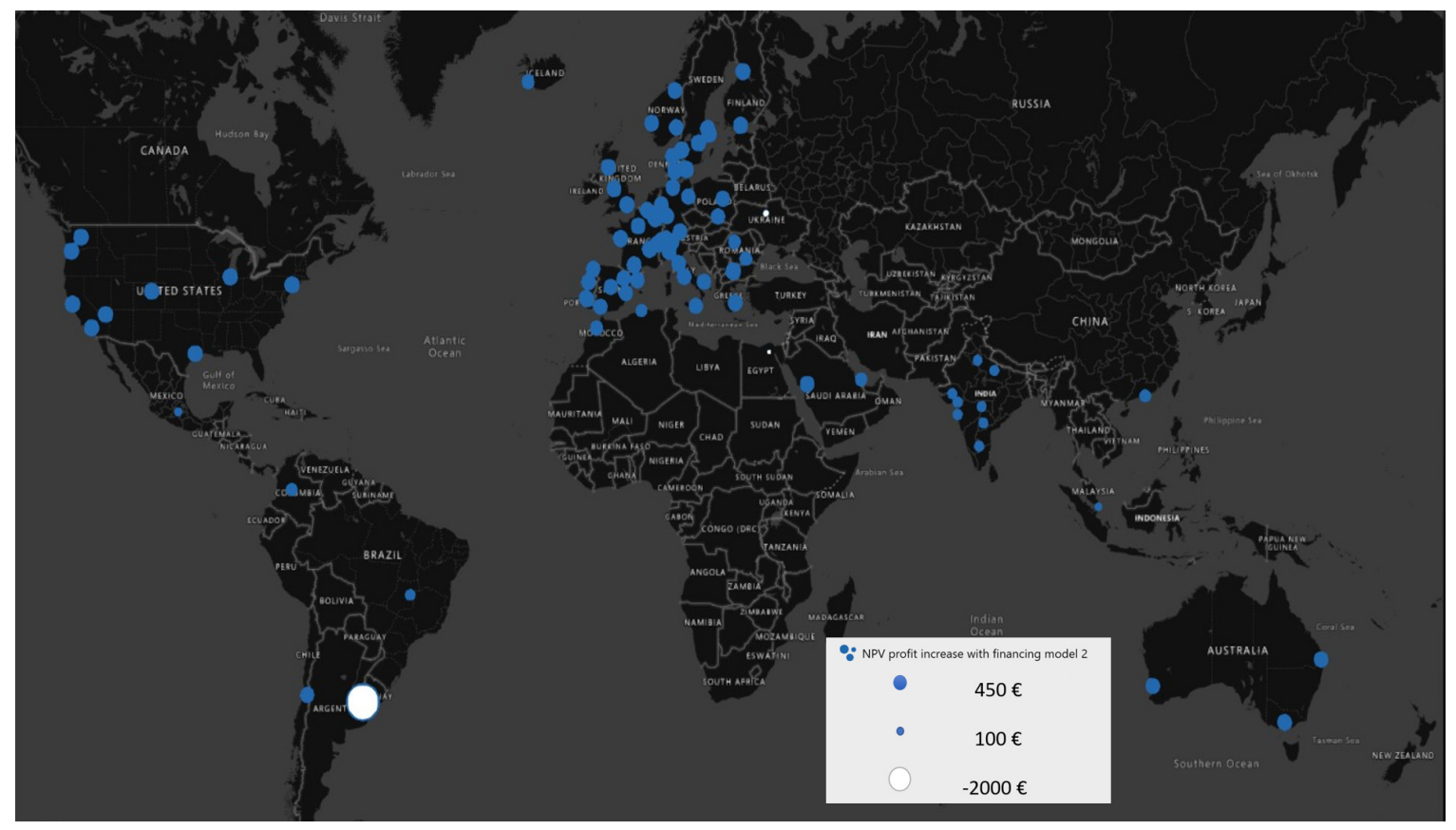

Figure 26. NPV profit increase with financing model 2.

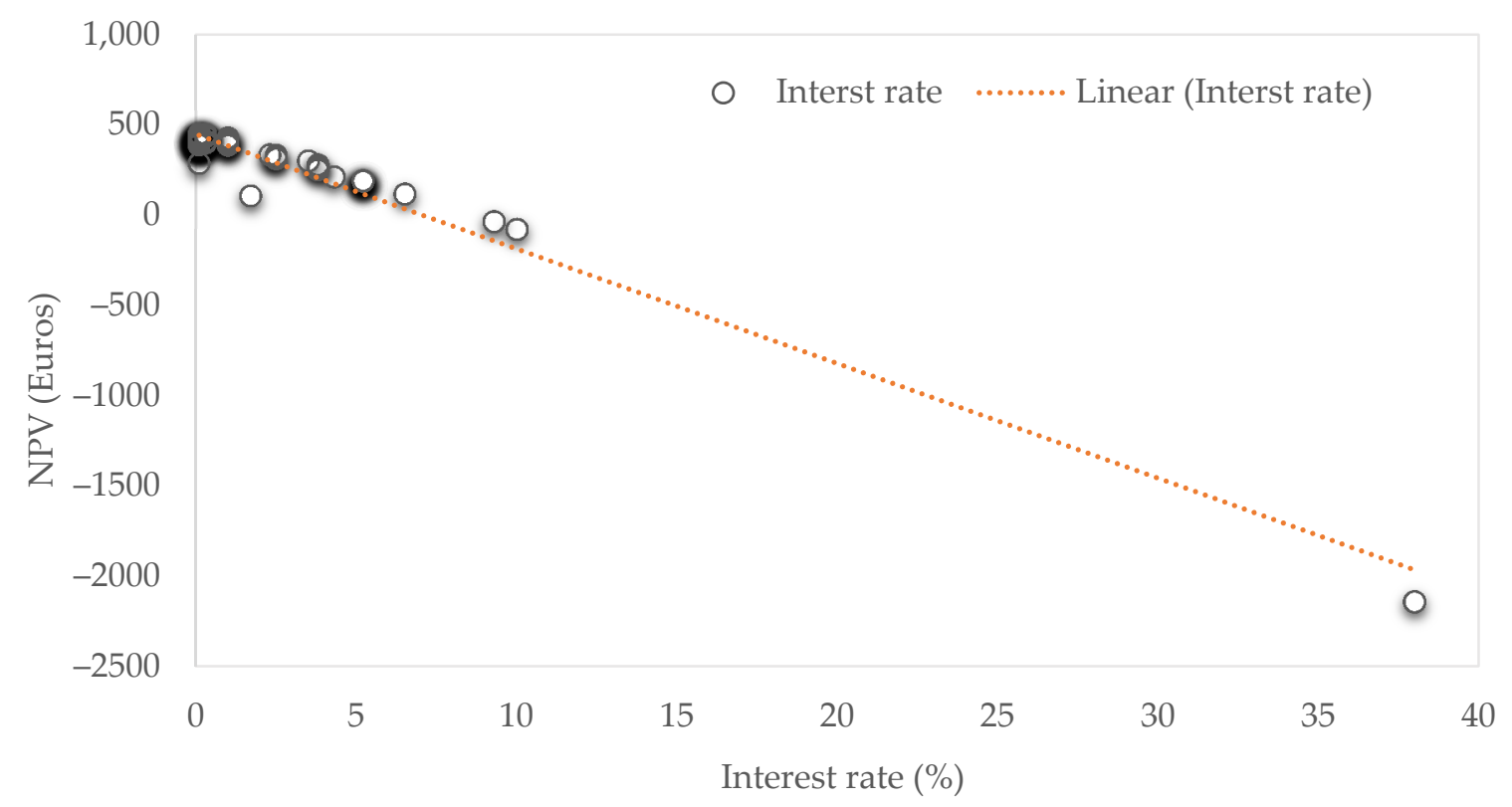

Figure 27. Correlation of NPV potential variation with interest rate.

Furthermore, as the grid price is a key parameter of the total system energy savings, the auxiliary energy price is taken as the generalized price for every specific country, whereas in the real-time case, the energy price would be different for every state/city/municipality depending on localized energy policy. It has been considered because of the unavailability of precise data, which may not be significantly higher. The interest rate is chosen for each country for deriving the NPV potential difference between financing model 1 and model 2. However, only a few countries which have negative and zero interest rate have been assumed as $0.1 \%$, due to the incapability of the simulation tool in accepting negative or null values. However, it has also been realized that the uncertainty of difference between the negative interest rates and assumed interest rates has not been less than $1 \%$, which is not 
significantly affecting the NPV potential difference. Hence, the assumptions have been considered to achieve the aims in possible optimistic and realistic approaches irrespective of the uncertainties.

\section{Conclusions}

The performance of a solar PVT consists of PVT collector and storage tank is evaluated for 85 locations across large cities. The optimal tilt angle of the PVT collector, load demand, and electricity prices are chosen appropriately for each simulated location. The results show that the major parameter influencing the PVT performance is GHI, and results derived a strong linear correlation between collector output and GHI. The other factor influencing energetic performance is ambient temperature, source, and load water temperatures. The energetic utilization ratio is dependent on total thermal demand and specific volume ratio (v/a ratio) as it can have a major influence on the fluid temperature in the storage tank and, thus, collector total production. The electrical production by PVT collector is higher in high ambient temperature locations. The highest and lowest energy utilization ratio of the collector is recorded in Reykjavik, Iceland (63\%), and Medina, Saudi Arabia (54\%), respectively. The highest and lowest exergetic efficiency of the collector has been recorded in Reykjavik, Iceland (23\%), and Medina, Saudi Arabia (17\%), respectively. Most importantly, the results show that the higher energetic output does not guarantee high economic feasibility. There are several factors such as electricity price, interest rate, and selection of financial model which can highly affect the economic feasibility of PVT collector. The average NPV per unit collector area of 85 geographical cities for financial model 1 and financial model 2 is 1886 and 2221 EUR, respectively. The NPV and payback period analysis of the PVT system has shown positive results for the cities, which have high collector production and high electricity grid price reflecting high energy savings. However, the financing model 1 is highly recommended for the locations with high interest rates and financial model 2 is beneficial for the locations with less interest rates. This paper offers potential insights into the promotion of the PVT market in different regions.

Author Contributions: S.R.P. worked on simulation, analysis, and writing. X.Z. contributed to supervision, concept development, structuring, and writing. P.K.S. contributed to simulation, analysis, and writing. A.d.A. dedicated efforts to simulation and analysis. All authors have read and agreed to the published version of the manuscript.

Funding: This research received funding from the Germany-Sweden joint project: 'Product and process development for the preparing and realization of complete buildings of various types of use using energy efficient, partially energy independent lightweight construction solutions, ENSECO'.

Acknowledgments: The authors acknowledge the useful gains from the IEA SHC Task 60, and the open access support from Dalarna University, Sweden.

Conflicts of Interest: The authors declare no conflict of interest.

\section{References}

1. Sommerfeldt, N.; Madani, H. In-depth techno-economic analysis of PV/Thermal plus ground source and heat pump systems for multi-family houses in a heating dominated climate. Sol. Energy 2019, 190, 44-62. [CrossRef]

2. Joshi, S.; Dhoble, A.S. Photovoltaic-Thermal systems (PVT): Technology review and future trends. Renew. Sustain. Energy Rev. 2018, 92, 848-882. [CrossRef]

3. Al-Waeli, A.H.; Sopian, K.; Kazem, H.A.; Chaichan, M.T. Photovoltaic/Thermal (PV/T) systems: Status and future prospects. Renew. Sustain. Energy Rev. 2017, 77, 109-130. [CrossRef]

4. Gu, Y.; Zhang, X.; Myhren, J.A.; Han, M.; Chen, X.; Yuan, Y. Techno-economic analysis of a solar photovoltaic/thermal (PV/T) concentrator for building application in Sweden using Monte Carlo method. Energy Convers. Manag. 2018, 165, 8-24. [CrossRef]

5. PVT Systems IEA SHC 60-Annex 180504.pdf. Available online: http://task60.iea-shc.org/Data/ Sites/1/publications/PVT\%20systems\%20IEA\%20SHC\%2060\%20-\%20Annex\%20180504.pdf (accessed on 25 November 2019). 
6. Zhang, X.; Zhao, X.; Smith, S.; Xu, J.; Yu, X. Review of R\&D progress and practical application of the solar photovoltaic/thermal (PV/T) technologies. Renew. Sustain. Energy Rev. 2012, 16, 599-617. [CrossRef]

7. Ramschak, T. IEA SHC Task 60. 2020. Available online: https://task60.iea-shc.org/Data/Sites/1/publications/ IEA-SHC-Task60-A1-Existing-PVT-Systems-and-Solutions.pdf (accessed on 29 July 2020).

8. IEA-SHC-Task60-Highlights-2019.pdf. Available online: https://task60.iea-shc.org/Data/Sites/1/publications/ IEA-SHC-Task60-Highlights-2019.pdf (accessed on 10 June 2020).

9. Buonomano, A.; De Luca, G.; Figaj, R.; Vanoli, L. Dynamic simulation and thermo-economic analysis of a PhotoVoltaic/Thermal collector heating system for an indoor-outdoor swimming pool. Energy Convers. Manag. 2015, 99, 176-192. [CrossRef]

10. Riggs, B.C.; Biedenharn, R.; Dougher, C.; Ji, Y.V.; Xu, Q.; Romanin, V.; Codd, D.S.; Zahler, J.M.; Escarra, M.D. Techno-economic analysis of hybrid PV/T systems for process heat using electricity to subsidize the cost of heat. Appl. Energy 2017, 208, 1370-1378. [CrossRef]

11. Wang, K.; Herrando, M.; Pantaleo, A.M.; Markides, C.N. Technoeconomic assessments of hybrid photovoltaic-thermal vs. conventional solar-energy systems: Case studies in heat and power provision to sports centres. Appl. Energy 2019, 254, 113657. [CrossRef]

12. Kazem, H.A. Evaluation and analysis of water-based photovoltaic/thermal (PV/T) system. Case Stud. Therm. Eng. 2019, 13, 100401. [CrossRef]

13. Fudholi, A.; Sopian, K.; Yazdi, M.H.; Ruslan, M.H.; Ibrahim, A.; Kazem, H.A. Performance analysis of photovoltaic thermal (PVT) water collectors. Energy Convers. Manag. 2014, 78, 641-651. [CrossRef]

14. Khelifa, A.; Touafek, K.; Ben Moussa, H.; Tabet, I.; Hocine, H.B.C.E.; Haloui, H. Analysis of a Hybrid Solar Collector Photovoltaic Thermal (PVT). Energy Procedia 2015, 74, 835-843. [CrossRef]

15. Khelifa, A.; Touafek, K.; Ben Moussa, H.; Tabet, I. Modeling and detailed study of hybrid photovoltaic thermal (PV/T) solar collector. Sol. Energy 2016, 135, 169-176. [CrossRef]

16. Gagliano, A.; Tina, G.M.; Nocera, F.; Grasso, A.D.; Aneli, S. Description and performance analysis of a flexible photovoltaic/thermal (PV/T) solar system. Renew. Energy 2019, 137, 144-156. [CrossRef]

17. Shah, R.; Srinivasan, P. Hybrid Photovoltaic and Solar Thermal Systems (PVT): Performance Simulation and Experimental Validation. Mater. Today Proc. 2018, 5, 22998-23006. [CrossRef]

18. Buonomano, A.; Calise, F.; Vicidomini, M. Design, Simulation and Experimental Investigation of a Solar System Based on PV Panels and PVT Collectors. Energies 2016, 9, 497. [CrossRef]

19. Yazdanpanahi, J.; Sarhaddi, F.; Adeli, M.M. Experimental investigation of exergy efficiency of a solar photovoltaic thermal (PVT) water collector based on exergy losses. Sol. Energy 2015, 118, 197-208. [CrossRef]

20. Herrando, M.; Markides, C.N. Hybrid PV and solar-thermal systems for domestic heat and power provision in the UK: Techno-economic considerations. Appl. Energy 2016, 161, 512-532. [CrossRef]

21. Ahn, H.; Rim, D.; Pavlak, G.S.; Freihaut, J.D. Uncertainty analysis of energy and economic performances of hybrid solar photovoltaic and combined cooling, heating, and power (CCHP + PV) systems using a Monte-Carlo method. Appl. Energy 2019, 255, 113753. [CrossRef]

22. Heck, N.; Smith, C.; Hittinger, E. A Monte Carlo approach to integrating uncertainty into the levelized cost of electricity. Electr. J. 2016, 29, 21-30. [CrossRef]

23. Jung, J.; Han, S.; Kim, B. Digital numerical map-oriented estimation of solar energy potential for site selection of photovoltaic solar panels on national highway slopes. Appl. Energy 2019, 242, 57-68. [CrossRef]

24. Oh, M.; Park, H.-D. A new algorithm using a pyramid dataset for calculating shadowing in solar potential mapping. Renew. Energy 2018, 126, 465-474. [CrossRef]

25. Mishra, T.; Rabha, A.; Kumar, U.; Arunanchalam, K.; Sridhar, V. Assessment of solar power potential in a hill state of India using remote sensing and Geographic Information System. Remote Sens. Appl. Soc. Environ. 2020, 100370. [CrossRef]

26. Bremer, M.; Mayr, A.; Wichmann, V.; Schmidtner, K.; Rutzinger, M. A new multi-scale 3D-GIS-approach for the assessment and dissemination of solar income of digital city models. Comput. Environ. Urban Syst. 2016, 57, 144-154. [CrossRef]

27. Peronato, G.; Rastogi, P.; Rey, E.; Andersen, M. A toolkit for multi-scale mapping of the solar energy-generation potential of buildings in urban environments under uncertainty. Sol. Energy 2018, 173, 861-874. [CrossRef]

28. Chow, T.-T. A review on photovoltaic/thermal hybrid solar technology. Appl. Energy 2010, 87, 365-379. [CrossRef] 
29. Joshi, A.S.; Tiwari, A. Energy and exergy efficiencies of a hybrid photovoltaic-thermal (PV/T) air collector. Renew. Energy 2007, 32, 2223-2241. [CrossRef]

30. IEA-SHC-Task60-B2-Design-Guidelines-for-PVT-Collectors.pdf. Available online: https://www.iea-shc. org/Data/Sites/1/publications/IEA-SHC-Task60-B2-Design-Guidelines-for-PVT-Collectors.pdf (accessed on 27 July 2020).

31. IEA SHC||Task 60||IEA SHC||Task 60. Available online: http://task60.iea-shc.org/ (accessed on 21 November 2019).

32. 'Contact', Abora Solar. Available online: https://abora-solar.com/en/contact/ (accessed on 29 November 2019).

33. Microsoft Excel, Spreadsheet Software, Excel Free Trial. Available online: https://www.microsoft.com/enww/microsoft-365/excel (accessed on 29 July 2020).

34. Welcome to the QGIS Project! Available online: https://qgis.org/en/site/ (accessed on 29 July 2020).

35. 'Intro', Meteonorm (de). Available online: https://meteonorm.com/ (accessed on 22 July 2020).

36. Al-Ghussain, L.; Taylan, O.; Baker, D.K. An investigation of optimum PV and wind energy system capacities for alternate short and long-term energy storage sizing methodologies. Int. J. Energy Res. 2018, 43, $204-218$. [CrossRef]

37. 'India Electricity Prices, June 2019|GlobalPetrolPrices.com', GlobalPetrpPrices.com. Available online: https://www.globalpetrolprices.com/India/electricity_prices/ (accessed on 15 March 2020).

(C) 2020 by the authors. Licensee MDPI, Basel, Switzerland. This article is an open access article distributed under the terms and conditions of the Creative Commons Attribution (CC BY) license (http://creativecommons.org/licenses/by/4.0/). 